\title{
As dimensões antropológicas do aborto
}

\section{A abordagem comparatista de George Devereux}

Fazer referência às práticas naquilo que elas possuem de mais geral em sua dimensão antropológica - não é atualmente bem visto nas ciências sociais que, sem dúvida, jamais admitiram tanto quanto hoje a separação entre disciplinas voltadas para a cultura e disciplinas voltadas para a natureza. ${ }^{1}$ Sobre estas, repousaria todo o projeto de um levantamento das invariantes, cujo caráter universal viria de seu enraizamento na biologia (particularmente, na ancoragem biológica da mente) ou, o que é mais ou menos o mesmo, dos efeitos de imposições determinadas pelos caracteres biológicos dos seres humanos (que se alimentam, se reproduzem, morrem etc.) sobre a vida em sociedade. Às disciplinas voltadas para a cultura caberia, ao contrário, a tarefa de inventariar o restante, isto é, as diferenças entre os grupos humanos, resultantes principalmente da adesão a sistemas diferentes de crenças. $\mathrm{Na}$ ordem da natureza, tudo seria por toda parte idêntico. Na da cultura, tudo seria diferente. Ora, foi precisamente contra essa divisão, que o positivismo tornara tão pregnante, que se constituíram, há mais de um século, a sociologia geral e a antropologia social, cujo projeto foi estabelecido já de início como comparatista. A sociologia geral e a

Do original "Les dimensions anthropologiques de l'avortement", publicado como capítulo 1 do livro La condition foetale: une sociologie de l'engendrement et de l'avortement (Paris: Gallimard, 2004). Direitos concedidos por Éditions Gallimard. Tradução de Patrícia C. R. Reuillard. Revisão da tradução por Luis Felipe Miguel. 
antropologia social assumiram, assim, a tarefa principal de inventariar a maneira como práticas (por exemplo, no caso da corrente durkheimiana, o sacrifício, a oração, a troca, o parentesco, as práticas classificatórias, o juramento, o crime etc.), que apresentavam certa semelhança, podiam ser realizadas, todavia, de acordo com modalidades diferentes, em diferentes sociedades. A mesma observação pode ser feira acerca da psicanálise que, ao menos após seu encontro com a antropologia cultural, decidira, sem abandonar seus conceitos fundamentais (inconsciente, recalcamento etc.), examinar, por exemplo, como diferentes tipos de organização das pulsões inconscientes podiam corresponder a diferentes práticas de socialização, ou como a consideração das tensões próprias a cada cultura permitia traçar caminhos para passar dos mitos coletivos aos sonhos individuais, e reciprocamente.

Em relação ao nosso objeto, George Devereux - antropólogo social e psicanalista - foi o primeiro a estudar de modo sistemático a prática do aborto, considerando-a em suas dimensões gerais e, ao mesmo tempo, nas formas específicas que ela assumiu em diferentes sociedades. Quando publica, em 1955, A study of abortion in primitive society, a meta de Devereux é, conforme explica na introdução do livro, de ordem teórica ou, antes, "metodológica". Ele pretende atingir quatro objetivos: a) sustentar empiricamente a validade do "axioma segundo o qual a diversidade cultural demonstra a formidável plasticidade e variabilidade do comportamento humano"; b) fornecer um material empírico para "provar o teorema de que a análise de uma única instituição em uma única sociedade pode fornecer as bases de conclusões universalmente válidas" (em referência a Durkheim e a Freud) e, ao contrário, que se "pode chegar às mesmas conclusões tomando por objeto as variações de um mesmo traço cultural ou de uma mesma instituição em um grande número de sociedades”, de modo a "justificar simultaneamente as pesquisas em profundidade e as pesquisas extensivas"; c) demonstrar a compatibilidade da abordagem antropológica e da abordagem psicanalítica, por existir uma correspondência exata entre os comportamentos culturais e os afetos ${ }^{2}$. Devereux acredita

\footnotetext{
"Se os antropólogos fossem capazes de listar todos os tipos de comportamentos culturais, essa lista recobriria ponto por ponto todas as pulsões, desejos, fantasias, etc., que os psicanalistas levantam em um contexto clínico e, por consequência, de demonstrar a unidade psíquica da espécie humana" (Devereux, 1955, introdução).
} 
que o aborto constitui uma prática que se presta particularmente bem à demonstração que ele pretende fazer porque - e veremos a importância desse traço para nós - "em lugar algum ela ocupa uma posição central na cultura", de modo que, por não ser objeto de "prescrições culturais" precisas e explícitas, ela deixa amplamente aberta a possibilidade de uma grande diversidade de comportamentos individuais; enfim, d) último objetivo da obra: apresentar um material mais ou menos exaustivo sobre o aborto para facilitar pesquisas futuras.

Devereux coletou, de fato (e publicou metodicamente como anexo de seu livro), um corpus de estudo sobre quatrocentas "sociedades pré-industriais". Como fonte principal, utilizou os Human relations area files, da Universidade de Yale, guiado por Ralf Linton (que, pouco antes de sua morte, entrara para o departamento de antropologia dessa universidade) e, sobretudo, por George Peter Murdock, o antropólogo que, a partir de 1938, criara os Area files com o fim de desenvolver uma antropologia comparativa e "transcultural". Devereux completou sua documentação com arquivos pessoais e com comunicações, verbais ou escritas, fornecidas por diferentes colegas. Os Area files são um imenso arquivo constituído a partir do levantamento de quase toda a literatura antropológica conhecida (publicada em livro ou em artigos ou sob forma de manuscritos inéditos) e também do que se pode chamar de importante literatura pré-antropológica (relatos de viajantes, de missionários, de administradores coloniais, etc.) considerada como possuindo um valor documental suficientemente confiável. Os dados são registrados nesse arquivo de acordo com um sistema duplo de classificação: de um lado, por áreas culturais e por sociedades, de outro, por temas. Há uma entrada dedicada às questões relativas à gravidez e ao aborto e uma subentrada indexando o aborto $^{3}$. Desde a época em que Devereux constituiu esse corpus, os Area files continuaram sendo alimentados. O laboratório de antropologia social do Collège de France, em Paris, possui uma cópia desse arquivo em três suportes diferentes (devido à antiguidade das fichas e às escolhas de transcrição informática): em fichas de papel, em CD-ROM e on-line, por meio de assi-

\footnotetext{
Há outro estudo, realizado entre 1940 e 1943, portanto mais de dez anos antes do trabalho de Georges Devereux, feito a partir dos Human relations area files, que traz dados sobre o aborto (p. 50-53), mas cuja ótica é mais ampla, já que esse trabalho concerne à "reprodução humana" em geral. Esse estudo, essencialmente descritivo (e, no plano teórico, de inspiração funcionalista), comporta informações ou sínteses de dados que utilizamos. Ele foi republicado em 1964 por Clellan Stearns Ford.
} 
natura, de modo que se pode completar (ou, em caso de dúvida, verificar) a informação contida na obra de Devereux, consultando esse arquivo ${ }^{4}$.

As informações contidas nos Area files dificilmente se prestam a um processamento sistemático - sem falar de um estatístico - principalmente porque a informação, coletada em períodos distintos, em sociedades muito diversas e com métodos díspares empregados por indivíduos diferentes tanto por suas competências como etnógrafos quanto por suas orientações teóricas, é muito heterogênea e de valor desigual. Como ressalta Devereux, acontece, por exemplo, de observações acerca de uma mesma sociedade feitas por pesquisadores diferentes não coincidirem. É preciso então se resignar a extrair desses levantamentos asserções que tangem mais à presunção do que à certeza factual.

Mesmo sem necessariamente compartilhar os pressupostos teóricos de Devereux, nem seguir todas as exposições (que contêm, com frequência, intuições notáveis) de um livro copioso, mas cuja construção é bastante desconcertante, é possível, apoiando-se em observações e notas deste compêndio e nos resultados de sondagens complementares nos Area files, delinear um quadro que desvele algumas das questões principais que a prática do aborto levanta para a sociologia. A título de hipótese, indicaremos quatro propriedades do aborto não explicitamente destacadas por Devereux, ou em que ele não se detém, mas para as quais convergem, entretanto, numerosas indicações contidas em seu material e também, por vezes, em suas análises.

\section{Uma prática cuja possibilidade é conhecida em todo lugar}

Uma primeira propriedade, claramente afirmada por Devereux, é o caráter provavelmente universal dessa prática ${ }^{5}$. Devereux indica que, no caso de cerca de $60 \%$ das sociedades registradas nos Area files, encontram-se informações sobre o aborto. Isso não significa, é claro, que o aborto seja desconhecido nas $40 \%$ restantes, mas apenas que, dado o caráter bastante heterogêneo da informação contida nesses arquivos, nem sempre os etnógrafos levaram em conta essa dimensão da existência em suas monografias ou seus informantes não falaram sobre isso. O que parece universal não é tanto, aliás, a prática do aborto voluntário, atestada de modo muito desigual, ao que parece,

Agradeço a Philippe Descola que facilitou meu acesso aos Area files, assim como a seus colaboradores, que me orientaram nas buscas.

A mesma constatação é feita por Ford (1964, p. 50). 
conforme as sociedades e conforme as épocas (embora dados estatísticos sólidos não possam quase nunca ser estabelecidos), mas o reconhecimento da possibilidade dessa prática. Não há registro de exemplo de situações em que um informante (e, mais ainda, uma informante), interrogado sobre esse ponto, ignore do que se trata ou se espante, caso lhe seja explicado, que isso possa acontecer. A possibilidade de tirar os fetos do ventre antes de seu nascimento com a intenção de destruí-los parece, portanto, fazer parte dos quadros fundamentais da existência humana em sociedade.

Os meios utilizados para este fim são muito numerosos e hoje bastante conhecidos, não somente nas sociedades estudadas pela etnologia, mas também nas sociedades antigas, particularmente da Antiguidade greco-romana, nas sociedades ocidentais medievais ${ }^{6}$ e modernas, na China e no Japão ${ }^{7}$. Os métodos mais difundidos são o uso de drogas abortivas, geralmente de origem vegetal (com efeitos eméticos, laxativos, purgativos, adstringentes etc.), conhecidas praticamente em todas as sociedades com informação disponível, de meios mecânicos, ou internos (com a introdução de um caule na vagina), ou externos (pulos, golpes, cintos apertando o ventre, aplicação de matérias quentes como água, cinzas e pedras sobre a parede abdominal etc.), ou uma combinação desses diferentes métodos, como a introdução de drogas na vagina e manipulação dos órgãos sexuais. Tais métodos, químicos ou mecânicos, têm correlação com cada uma das teorias locais referentes à reprodução e à gestação, sobre as quais repousa a confiança depositada em sua eficácia. São igualmente empregados meios mágicos (sentar-se sob determinada árvore, comer ou beber um certo alimento, carregar um amuleto, etc.). Esses meios mágicos, nitidamente distinguidos dos meios mecânicos ou químicos em geral, repousam muitas vezes na realização de um ato transgressivo (o alimento ingerido é proibido etc.). Devereux destaca a existência possível, entre os índios hopis, de um meio que ele denomina "psicossomático": o desejo intenso de abortar teria, por si só, efeitos abortivos. Na maioria das

\footnotetext{
Ver, principalmente, Riddle (1992).

Cf. a obra de La Fleur (1992), que estuda, do ponto de vista da demografia mas também da antropologia, a prática do aborto no Japão, particularmente nas épocas ditas pré-modernas e modernas. Ele correlaciona a prática do aborto a uma concepção "fluida" da vida; nessa concepção, os seres humanos deixam pouco a pouco o mundo dos deuses para entrar no dos seres humanos e, com a vinda da velhice, deixam igualmente de modo progressivo o mundo dos humanos para voltar ao dos deuses. O nascimento e a morte são assim concebidos como processos sociais "que se estendem no tempo e se realizam em parte no mundo dos humanos, em parte no dos deuses".
} 
sociedades cuja informação está disponível, parece que os meios usados para praticar um aborto são da ordem de um saber comum, mesmo que algumas pessoas (que, de hábito, têm também o papel de parteira) sejam tidas como mais conhecedoras ou mais hábeis do que outras. De fato, muitos dos meios empregados para provocar um aborto são difíceis de aplicar e conhecidos por serem mais ou menos perigosos. Eles causam medo, mas isso não impede que se recorra a eles quando a necessidade de abortar parece se impor.

\section{Objeto de uma reprovação geral}

Uma segunda propriedade do aborto é ser, geralmente, objeto de reprova$c ̧ a \tilde{a} o^{8}$. É muito raro que o aborto seja a priori aceito, inclusive nas sociedades em que sua prática é frequente. As reações vão da desaprovação chocada à mais violenta indignação acerca desse ato "vergonhoso" ou "horrível", cuja prática, aliás, é frequentemente atribuída aos povos vizinhos ou aos habitantes limítrofes, mas apresentada como desconhecida "entre nós". Tal indignação não parece ser somente fingida para satisfazer às expectativas de um observador estrangeiro que se imaginaria contrário ao aborto (por exemplo, nos casos de informação proveniente de relatos de viagem ou de lembranças de missionários); é igualmente mencionada nos relatórios dos etnógrafos mais profissionais. Tampouco se trata de uma atitude própria aos homens, pois as mulheres muitas vezes manifestam o mesmo "horror" à evocação desse ato, mesmo que nada impeça interpretar sua indignação como sinal de uma interiorização dos valores masculinos. $\mathrm{O}$ aborto é algo de que não se fala ou se fala com constrangimento, tendo o cuidado, na maioria das vezes, de mostrar claramente que, embora se saiba que "isso existe", tal prática não diz respeito nem aos próximos (os membros da parentela) nem mesmo ao coletivo a que se pertence.

Enfim, o grau de desaprovação expresso parece variar não somente conforme as sociedades, mas também em uma mesma sociedade, conforme as circunstâncias, em função de uma casuística que depende das características da cultura considerada. Por exemplo, geralmente, quando se suspeita de um incesto ou uma cópula com um animal (entre os índios navajos) ou, particularmente nas sociedades patrilineares, quando se presume que a mãe dará à luz um bastardo, sobretudo - salvo nas sociedades que admitem a multi-

A reprovação geral que sofre o aborto na maioria das sociedades é confirmada pelo trabalho já citado de Ford (1964, p. 51). 
paternidade 9 - quando a multiplicidade dos pais em potencial não permite identificar o verdadeiro pai e obrigá-lo a casar com a mulher grávida, ou ainda (entre os jívaros, como de resto em numerosas sociedades), quando se pensa que a mulher foi fecundada por um demônio e que ela dará à luz um monstro ${ }^{10}$ etc. A referência a essas circunstâncias atenuantes baseadas nas características do feto que, antes do aparecimento das técnicas modernas de imagens era uma incógnita, não deve, de resto, ser tomada de modo muito literal, como se estivesse ligada a provas específicas e controladas, mas, antes, porque delineia os contornos de um registro argumentativo mobilizável cada vez que se busca atenuar a reprovação ao aborto. Assim, o argumento de que uma mulher abortou porque a criança que traria ao mundo seria ilegítima (isto é, em muitas sociedades tradicionais, não teria tido nem nome nem parentes $\mathrm{Co}^{11}$ ) sempre tem algo que, pode-se dizer, "é evidente", embora na prática existam frequentemente outras alternativas, como encontrar para a jovem grávida um marido que aceite assumir a paternidade da criança.

\section{A tolerância ao aborto}

O fato de que a reprovação ao aborto parece ser, na maioria das vezes, acompanhada de uma grande tolerância da parte daqueles mesmos que se indignam com sua evocação pode ser considerado uma terceira propriedade importante do aborto. Embora inúmeros exemplos possam ser dados, em diferentes áreas, de variações entre a norma expressa - ou, nas sociedades em que existe um direito escrito, a lei - e as condições pragmáticas de sua aplicação, parece que, neste caso, a defasagem entre a regra e sua aplicação é particularmente patente e é encontrada, sob formas variáveis, na maioria das sociedades de que se tem informação. É muito raro que se façam grandes esforços para identificar as pessoas responsáveis pelo aborto, persegui-las e puni-las. Esse traço também vale para as sociedades ocidentais medievais

\footnotetext{
Entre os ianomâmis, principalmente, existe a crença de que a inscrição de uma criança na carne de uma mulher exige não um coito, mas uma série de emissões de esperma. Vários homens podem participar dessa fabricação progressiva. Porém, é reconhecido a um dos genitores, nesse engendramento múltiplo, um papel principal (Alès, 2002, p. 62-85).

10 É o caso também, por exemplo, dos índios marato, do Chaco, que acreditam que demônios podem penetrar no corpo das mulheres, quando tomam banho, para fecundá-las (Karsten, 1932, p. 77-78). Fonte: Area files. Na sequência, identificaremos as referências extraídas desse arquivo pelas iniciais (AF). ' Assim, os índios tinglit, cuja herança ancestral passa em parte pela linhagem materna, dizem que a criança sem pai é um "ser incompleto", que eles comparam a uma estátua de madeira inacabada (Kan, 1989-AF).
} 
ou modernas, dominadas por Igrejas cristãs cujos Pais haviam condenado o aborto; entretanto, antes da segunda metade do século XIX, digamos, as autoridades podiam às vezes censurar tal ato ou lembrar sua proibição, sem que isso tivesse muitos efeitos concretos - nem o de estimular investigações policiais nem o de modificar as práticas ${ }^{12}$. O fato de que as pessoas que abortam e aquelas que as auxiliam nessa prática não sejam, na maior parte das vezes, perseguidas ou punidas não significa, contudo, falta de sanções. Em inúmeras sociedades, os informantes mencionam sua existência, mas são sanções imanentes (como a esterilidade), ou difusas, que atingem o grupo parental ou até mesmo todo o coletivo ${ }^{13}$ (por exemplo, uma vingança exercida pelo espírito do feto abortado), como acontece frequentemente quando práticas transgressivas afetam a ordem do mundo.

Uma compilação de dados etnográficos permite extrair um outro traço intrigante, congruente com o par indignação-tolerância. Quando praticado, o aborto em geral é feito secretamente ou, ao menos, ao abrigo dos olhares. Porém, na maioria das vezes, é que se chama popularmente de "segredo de polichinelo". Esse tipo de figura deve atrair nossa atenção para uma oposição que exerce um papel importante em relação a nosso objeto: trata-se da oposição - cuja análise foi particularmente desenvolvida na obra etnológica de Pierre Bourdieu, principalmente nos textos consagrados ao parentesco

\footnotetext{
12 Também se pode, todavia, questionar se o fato de ser conhecido por praticar abortos não entraria no pacote de acusações diversas, frequentemente associadas a práticas que se supunha agir contra a fertilidade - dos seres humanos, dos solos ou dos animais domésticos - dirigidas contras as pessoas designadas como bruxas. Em um artigo que discute os inúmeros trabalhos consagrados à história da grande caça às bruxas na Europa dos séculos XVI e XVII, Richard Horsley busca esclarecer quais eram os papéis sociais das pessoas acusadas de bruxaria nos processos e esboça uma análise estatística a partir das deposições e das acusações. Ele mostra que as pessoas acusadas de bruxaria eram, na maioria das vezes, mulheres idosas, isoladas, solteiras ou viúvas, exercendo papéis de curandeiras ou adivinhos, quase sempre praticando uma "magia branca", que não implica a crença em relações demoníacas. As acusações formuladas pelos camponeses podiam ocorrer depois, dentre outras razões, do fracasso de práticas de atendimento. Mas não se encontra, nas acusações dos camponeses, referência a práticas diabólicas, que são produto da reinterpretação, nos termos da teoria oficial da bruxaria, de práticas populares de atendimento. Essas curandeiras podiam também exercer o papel de parteiras, não estando os dois papéis nitidamente distinguidos. Mas o número das pessoas explicitamente designadas como parteiras (midwifes) é modesto ao lado daquele das pessoas designadas como curandeiras (wise women). Enfim, a acusação de matar os recém-nascidos para comê-los ou entregá-los ao diabo desde o nascimento era formulada pelas autoridades oficiais, mas não figurava nas acusações dos camponeses. Tampouco se encontra, nas acusações levantadas por Horsley, referência explícita a práticas abortivas (Horsley, 1979, p. 680-715).

13 Os índios aymara da Bolívia, em quem a prática do aborto é atestada e não explicitamente reprimida, são no entanto desfavoráveis a ela porque pensam que está associada a chuvas de granizo com um caráter catastrófico (Buechler, 1971-AF).
} 
- entre o que concerne ao oficial, dotado de um caráter "público, solene, coletivo", e o que, tangendo ao oficioso, é condenado a um modo de existência "vergonhoso", até mesmo "clandestino"14. Essa oposição pode dizer respeito à distribuição de diferentes tipos de ação ou diferentes formas de poder. Nos estudos que Pierre Bourdieu consagrou à sociedade cabila, ela é correlacionada à oposição entre os homens e as mulheres, entre a sociedade masculina e a sociedade feminina; enquanto os homens detêm o poder oficial sobre o que é explicitamente coletivo e público, sobretudo sobre as representações do parentesco, domínio que Bourdieu salienta revestir um caráter eminentemente político nas sociedades tradicionais, as mulheres exercem um poder que, mesmo sendo real (principalmente, diz esse autor, em matéria de casamento), permanece oculto e "deixa aos homens as aparências".

A distinção, tematizada por numerosos antropólogos que estudaram as formas da dominação masculina ${ }^{15}$, entre o mundo dos homens, como mundo oficial - do direito, escrito ou consuetudinário, da religião, da política e da praça pública, do exterior - e o mundo das mulheres, como mundo oculto, "privado", oficioso - o do interior, da casa, da magia, da bruxaria - tem sem dúvida um caráter bastante geral. Ela abrange, em primeiro lugar, tudo o que concerne à gestação e ao nascimento, domínio que se limita, na maioria das sociedades tradicionais, ao segredo propriamente feminino, aquele que tem por lugar a casa (o interior em oposição ao exterior, correspondendo à oposição entre o público e o privado) e, no interior da casa, o espaço reservado às mulheres ${ }^{16}$, que, em muitas sociedades - por exemplo, entre os índios achuar estudados por Philippe Descola ${ }^{17}$, ou entre os baruya, estudados por Maurice Godelier (1996) -, é proibido aos homens ${ }^{18}$. Esse espaço da

\footnotetext{
14 Ver Bourdieu (1972), particularmente o terceiro estudo: "La parenté comme volonté et comme représentation".

15 Para um exemplo recente, ver Bourdieu (1997).

16 Sobre a distinção das "leis da casa" e das "leis da sociedade civil" e sobre o "segredo da sociedade das mulheres", onde se "desenrolarão até o século XVIII a maioria dos partos", ver Beaud (2001, p. 208-209 e 250-251).

7 Ver Descola (1998).

18 Catherine Alès fala assim do nascimento entre os ianomâmis: "o parto se desenrola sem a presença masculina: os homens, aterrorizados, escapam sistematicamente à visão dessa cena. As mulheres vão regularmente à floresta para parir, exceto à noite; vão para lá sozinhas ou acompanhadas de outra mulher, geralmente a mãe, ou, na falta desta, uma irmã ou cunhada (na maioria das vezes, se não moram na mesma aldeia, as esposas voltam a morar com a mãe nos últimos tempos da gravidez). Elas podem então decidir, por razões diversas, eliminar a criança imediatamente após o parto" (Alès, 1998, p. 281-315).
} 
casa escapa à lógica política da polis, ou seja, ao domínio da justiça e, mais profundamente, à "sociedade" no sentido moderno do termo ${ }^{19}$.

Deve-se ressaltar, todavia, que essa distinção entre o oficial e o oficioso é particularmente pertinente em relação ao nosso objeto. Dentre as práticas relacionadas ao pólo feminino, o aborto é sem dúvida uma das mais afastadas do espaço público, realizadas ao abrigo dos olhos e unicamente entre mulheres. Isso explica principalmente por que a informação sobre ele é tão lacunar e tão difícil de verificar, pelo menos quando comparada, por exemplo, com a informação disponível sobre as nomenclaturas de parentesco; fazendo parte do saber masculino, essas nomenclaturas puderam ser comunicadas por informantes homens a antropólogos do mesmo gênero sem dificuldade (aliás, foi necessário esperar a feminização profissional na antropologia, ao longo dos últimos trinta anos, para que se desenvolvesse realmente uma antropologia das práticas de engendramento). Retomando a distinção, destacada por Pierre Bourdieu, entre um poder masculino oficial e um poder feminino oficioso, pode-se ademais considerar que o aborto constitui o paradigma do poder propriamente feminino (em oposição ao poder sobre o parentesco e suas representações), particularmente nas sociedades tradicionais, onde as homologias entre o espaço político e o espaço doméstico conferem um caráter de grande importância a todas as práticas que dizem respeito à geração. Mas esse poder permanece, por si só, ilegítimo e oculto, quer seja instaurado sem o conhecimento dos homens e para lhes causar um dano (para se vingar de uma infidelidade do pai, suprimindo sua descendência), ou, ao contrário - os dois exemplos figuram nas nomenclaturas de "motivos" constituídas por Devereux -, com sua cumplicidade e em seu interesse, principalmente sexual (para que não tenham de se curvar aos interditos que concernem às relações sexuais durante a gravidez e a amamentação).

Porém, a distinção entre o oficial e público e o oficioso não se aplica somente ao campo da ação. Ela também pode apontar para modalidades diferentes do conhecimento, como no famoso exemplo, relatado por Malinowski, do jovem das Ilhas Tobriand que havia violado as regras da exogamia

\footnotetext{
19 Ver o modo como Aristóteles define a polis como o lugar onde se pode exercer a justiça, porque os seres humanos são separados, ao mesmo tempo em que dispõem de valores comuns suscetíveis de servir de base a divisões equânimes, por oposição, de um lado, à casa, onde os seres participam demais uns dos outros para tornar a justiça praticável e, de outro lado, às comunidades estrangeiras à polis, com as quais uma ordem justa não pode ser estabelecida devido agora à ausência de medida comum (Aristóteles, 1983, p. 248 ss.). Sobre essa distinção, ver também Arendt (1958, particularmente p. 65-76).
} 
com sua prima materna, filha da irmã de sua mãe. Tal fato era conhecido e desaprovado, mas sem maiores consequências até que o namorado da jovem insultasse o culpado publicamente, acusando-o, diante de toda a comunidade, de incesto. Na manhã seguinte, o jovem sobe em um coqueiro e, diante da comunidade reunida, lança-se no vazio e morre na hora (Malinowski, 2001 [1933], p. 68-71) ${ }^{20}$. O que está então em jogo não diz respeito a um diferencial de informação (a informação é a mesma, seja conhecida oficial ou oficiosamente), mas tange ao campo da acusação e, por conseguinte, da imputação de responsabilidade. Fatos podem ser conhecidos oficiosamente e não terem inconveniente enquanto ninguém assumir, por sua conta e risco, uma acusação pública; a situação se apresenta de modo bem diferente, contudo, se uma acusação pública é lançada, desencadeando um processo que deve culminar na determinação do caráter verdadeiro ou falso da acusação e, consequentemente, no exercício de sanções contra o culpado ou contra aquele que o acusou injustamente. Quando se diz que o aborto, mesmo sendo oficialmente condenado, é oficiosamente tolerado, também se faz referência a um processo desse tipo. Ele é tolerado não somente porque ocorre dentro de um contexto, o universo do feminino, impenetrável a partir do espaço público, não somente porque os esforços necessários para saber o que está acontecendo não são feitos, mas também porque, mesmo sabendo disso muito bem, de certo modo, pode-se agir como se o que se sabe não fosse pertinente ou se pode, por assim dizer, fechar os olhos e agir como se não se soubesse.

\section{A pobreza das representações}

Gostaríamos de terminar essa breve retomada dos traços gerais do aborto, que nos parecem particularmente pertinentes para instaurar uma problemática, propondo a existência de uma quarta propriedade que - e isso deve agravar nosso caso - não pode, ou pode muito dificilmente, ser objeto de uma demonstração formal, embora seja em nossa opinião muito provável, senão certa. Propomos, com efeito, a hipótese de que o aborto foi com muita frequência sub-representado (aliás, é isso provavelmente o que Devereux quer dizer ao afirmar que o aborto "em lugar algum ocupa uma posição central na cultura”). Essa propriedade é difícil de estabelecer porque

${ }^{20}$ Agradeço a Damien de Blic que chamou minha atenção para esse exemplo. 
isso suporia, por um lado, poder contar com um tipo de inventário de todas as representações conhecidas do aborto e, por outro, estar em condições de dar um sentido operacional à ideia de que existiria, para os diferentes tipos de práticas, um nível de certo modo "normal" de representação. Entretanto, é difícil de descartar a impressão de estar, nesse caso, em presença de um déficit de representação ou, de forma mais geral, de uma reticência coletiva para transcrever o aborto e o feto abortado em um registro simbólico.

De fato, o aborto ou os fetos abortados não parecem ter sido figurados com frequência em objetos ou em imagens, nem nas sociedades primitivas ou tradicionais, nem na Antiguidade, nem na pintura ocidental (existem no Japão, todavia, representações de um monstro, Kappa, que evoca um recém-nascido morto e/ou um feto, e bonequinhos, os kokeshi, que representam uma criança abortada e aos quais se fazem oferendas às vezes [Jolivet, 2002, p. 81-115]). Talvez o aborto seja uma prática difícil de mostrar, mas poderia ser mais facilmente contada. Ora, parece que ela também está ausente (ao menos até um período mais recente) dos relatos ou neles figura apenas em termos velados. É difícil encontrar referências diretas ao aborto em mitos, contos ou obras literárias, pelo menos anteriores aos romances naturalistas. Nestes se encontram referências relativamente pouco numerosas ao aborto (de resto, um tanto confundido com o infanticídio), escritas em tom crítico, depois de a proibição do aborto e, consequentemente, sua inscrição na lei do século XIX, ter conferido a essa prática uma visibilidade médica e jurídica como "flagelo social", associado, nas classes populares, ao alcoolismo e à prostituição, a partir de uma temática inspirada nos higienistas. Porém, sobretudo nos últimos trinta anos, encontram-se representações diretas do aborto em obras literárias ou cinematográficas. Entretanto, mesmo nesse caso, a narrativa em palavras ou imagens é, na maior parte das vezes, acompanhada de justificativas políticas ou morais que a inserem em uma crítica à ordem existente. Raramente as narrativas são dadas tais quais, sem necessitar de justificativa. Prática corrente (na França, sem dúvida, havia um aborto a cada dois nascimentos, até os progressos recentes da contracepção; cerca de um aborto em cada três ou quatro nascimentos hoje em dia, conforme os anos e os modos de contagem estatísticos), o aborto nunca é tratado como uma prática usual.

Pode-se observar igualmente que, à exceção dos textos de orientação médica, o aborto raramente é mencionado nas obras filosóficas e foi totalmente 
ignorado pela filosofia clássica. Sua possibilidade não teve nenhum efeito, ao que parece, sobre as concepções que a filosofia ocidental desenvolveu acerca da condição humana, diferentemente, por exemplo, do suicídio (igualmente um objeto de predileção da sociologia desde a constituição dessa disciplina). Existem referências ao aborto em textos normativos ocidentais de ordem religiosa, jurídica ou médica - especialmente em certos Pais da Igreja -, mas elas são relativamente raras, em geral pouco desenvolvidas e provavelmente reservadas a círculos estreitos.

Enfim, em lugar algum o aborto parece estar associado a uma forma ou outra de ritualismo ou de simbolismo. Os fetos abortados são grosseiramente enterrados, queimados ou afogados sem que essa destruição seja acompanhada de gestos ou palavras específicos. Todavia, parece haver em numerosas sociedades (e talvez praticamente em todas) a crença de que os fetos abortados se transformam em espíritos e, em certos casos, espíritos particularmente malvados e perigosos (sobretudo entre os hopis), dos quais seria melhor se precaver pronunciando certas orações ${ }^{21}$.

$O$ fato de o aborto ter sido mantido em larga medida afastado da esfera de representação pode ser correlacionado a duas propriedades que já mencionamos: de um lado, sua ligação com o mundo oficioso das práticas femininas; de outro, por se tratar de uma prática geralmente reprovada e por isso considerada (oficialmente) transgressiva. Esses argumentos parecem, no entanto, insuficientes. Podemos dar exemplos de práticas estritamente femininas que receberam inúmeras representações (como práticas homossexuais) e, mais claramente ainda, de outras francamente transgressivas que, por isso mesmo, figuraram com bastante frequência em mitos, narrativas, imagens etc., tais como o incesto, o assassinato familiar e também o infanticídio, seguidamente representado, segundo afirma Muriel Jolivet no artigo já citado, nas paredes dos monastérios budistas, entre a era Edo e a era Meiji, quando essa prática era muito difundida no Japão (Jolivet, 2002).

Essa sub-representação do aborto deve sem dúvida ser relacionada a uma ordem de fatos mais geral que concerne, até um período recente, à quase ausência do feto no campo das relações sociais nas quais estão presentes não somente seres humanos atuais, mas também, conforme os casos, mortos, ani-

${ }^{21}$ Devereux dá um exemplo (1955, p. 46) de invocação pronunciada pelos Rhadé Moi, estudados por Jouin (1949, p. 124-126), e destinada a apaziguar a cólera dos espíritos dos fetos abortados a quem"o arroz não foi oferecido, a água não foi dada". 
mais ou plantas, seres sobrenaturais, até mesmo seres futuros etc. É verdade que um grande número de sociedades ditas primitivas desenvolveu, em níveis aliás muito desiguais, ideias sobre a concepção, a gestação e a geração ${ }^{22}$. Nas sociedades ocidentais, desde a Antiguidade, encontram-se ideias desenvolvidas essencialmente por médicos (com repercussões na filosofia natural e na teologia), sobre a geração e, portanto, sobre o feto ${ }^{23}$, mas essas ideias ficam restritas a campos de saber relativamente limitados e não asseguram uma verdadeira presença do feto na sociedade. Socialmente, para as pessoas comuns e para as instituições, o que predomina é, por um lado, a mulher grávida e, por outro, o bebê. Até recentemente, o feto não era reconhecido como um ser dotado de identidade específica e valendo por si mesmo, como revelam sobretudo a pobreza de sua representação, o caráter limitado do corpus jurídico concernente ao tema ou a quase ausência de rituais acompanhando, em caso de aborto espontâneo - ou, como acabamos de ver, provocado - sua partida do mundo dos vivos para o dos mortos. De fato, descartando os bonequinhos e imagens destinados à instrução dos médicos e das parteiras, que se multiplicam sobretudo a partir da segunda metade do século XVIII ${ }^{24}$, o feto é estranhamente pouco presente tanto na representação visual (raridade de imagens religiosas, representando Cristo no seio da Virgem, enquanto feto ${ }^{25}$ ) quanto na poesia, na literatura, no mito, no discurso em geral. Do mesmo modo, apesar das especificações do direito romano destinadas a resolver problemas difíceis em matéria de herança ${ }^{26}$, o feto pouco aparece no direito e na religião, é quase ausente da polis, da política e, geralmente, das construções simbólicas que se sobrepõem à ordem social e a constituem enquanto tal. Quando deixa o útero antes do termo e não sobrevive, não recebe nome nem passa por um ritual funerário. Ora, ser objeto de ritos funerários é um indício muito importante do pertencimento à sociedade dos seres humanos (os pré-historiadores veem na presença desse tipo de rituais um critério ao qual eles atribuem um papel determinante no processo de humanização ${ }^{27}$ ). Mal se pode dizer que o feto

\footnotetext{
22 Ver Godelier e Panoff (eds., 1998).

23 Ver, dentre inúmeras obras, Gélis (1984). Ver também, para a Idade Média, Van der Lugt (1998).

24 Ver inúmeros exemplos em Gélis (1988).

${ }^{25}$ Existem muitos ícones da Virgem que têm, no lugar do seio, uma representação de Jesus, mas como criança já formada e revestida dos sinais da realeza divina, o que remete à simbólica da encarnação. (Ver o ícone russo do século XIV, da Virgem Maria do Sinal, ilustração de Isaías 7, 14, conservado na coleção de Chevelogne).

${ }^{26}$ Ver Thomas (1996, p. 212-235).

27 Ver Tattersall (1998).
} 
"morre", pois tudo se passa como se fosse necessário ter nascido, e nascido vivo, para poder morrer. Essa ausência é ainda mais surpreendente na história da filosofia ocidental que, excetuando os textos gregos sobre a natureza como phusis $^{28}$ e seus desenvolvimentos na filosofia natural, pouco levou em consideração esse estado dos seres humanos. Isso vale, em particular, para a filosofia clássica, que se voltou constantemente para o horizonte da mortalidade para construir uma ontologia, inclusive política ${ }^{29}$, da humanidade e que, com raríssimas exceções, ignorou não somente o feto mas também, de modo mais geral, a própria natalidade ${ }^{30}$, como observa Ricœur na obra que consagrou à relação entre memória e história (Ricœur, 2000, p. 465).

\section{Questões que o aborto levanta para a sociologia}

As poucas indicações que precedem, por mais parcelares que sejam, sugerem que várias das propriedades do aborto poderiam conferir a esse objeto um caráter particularmente instigante e problemático para uma sociologia da norma. Destacaremos particularmente duas questões, que buscaremos esclarecer nesta obra. A primeira diz respeito à legitimidade do aborto e seu lugar em relação à oposição entre o proibido e o permitido. De fato, o aborto parece estar suspenso entre o que tange ao transgressivo e o que tange ao aceitável e, assim, condenado a flutuar entre essas duas posições extremas. Geralmente reprovado em princípio, mas com frequência tolerado na prática, como se fosse difícil admitir sua legitimidade quando a questão da validade desse ato se encontra colocada em toda generalidade, mas fosse sempre possível desculpá-lo em certas situações e, sobretudo, fechar os olhos para essa possibilidade, ignorá-la.

\footnotetext{
${ }^{28}$ Mas, quando for preciso, na segunda metade do século XX, encontrar uma linguagem para qualificar juridicamente o"embrião", voltar-se-á para uma interpretação pouco exigente da oposição aristotélica entre ato e potência retraduzida no discurso da"virtualidade". Ver Aristóteles (1998) e, para uma história da posteridade das categorias aristotélicas, Pichot (1993).

29 De fato, é colocando os seres humanos frente à mortalidade e ao medo da morte que é construída a maioria das ontologias do social que podem ser chamadas de clássicas, quer se trate de erigir a necessidade do soberano (isto é, de um princípio de totalização suscetível de estancar a fragmentação) sobre o medo da morte violenta com que o outro nos ameaça, como em Hobbes, ou de fundar a instituição, este ser mais forte para os homens do que os próprios homens, sobre a possibilidade da morte como morte doce, comum, igualitária, aquela à que ninguém escapa, nem mesmo o rei ao qual um segundo corpo permite, entretanto, superar a finitude que determina o primeiro (Kantotorowicz, 1989).

30 Hannah Arendt foi um dos raros autores, dentre os filósofos, a esboçar uma metafísica da natalidade como paradigma do surgimento da temporalidade de eventos radicalmente novos (ver Arendt, 1983, p. 277-278).
} 
Uma segunda questão, que acreditamos relacionada à que acabamos de evocar, liga-se à relação entre a generalidade do aborto e sua visibilidade. Com certeza universalmente conhecido em sua possibilidade e sem dúvida também muito frequente em sua prática (ainda que de modo desigual conforme as sociedades e os períodos da história), o aborto permanece ainda assim, na maioria das vezes, à sombra. Aliás, é por ser provavelmente deixada à sombra que essa prática pode se manter em uma posição ambígua, sem que a tensão entre o aceitável e o proibido seja forte demais. Enquanto possibilidade, evita-se falar dele. Já sua prática é, no mais das vezes, dissimulada, mas de maneira que oscila entre a clandestinidade propriamente dita (em particular durante o período que vai de meados do século XIX à segunda metade do século XX, quando o aborto passou a ser ilegal e penalizado nos países ocidentais) e a prática discreta, que permite que aqueles que não querem saber ajam como se ele não existisse (como ocorreu no Ocidente até o século XIX). É precisamente essa discrição que torna difícil o estudo do aborto, não apenas porque as fontes antropológicas e históricas que lhe dizem respeito são raras e lacunares, mas também porque, na sociedade contemporânea onde o aborto é todavia legalizado, as pessoas que passaram por isso se mostram frequentemente reticentes a falar, mesmo a um sociólogo que garanta o anonimato. Mas o que é mais intrigante ainda é o fato de que o aborto é raramente representado, e essa característica o opõe tanto às práticas legítimas, frequentemente figuradas ou narradas para servirem de exemplo em um espírito de celebração, quanto às práticas francamente ilegítimas e transgressivas (tais como o incesto, o assassinato, o roubo, etc.), igualmente representadas e narradas, mas em um espírito de crítica, para dissuadir as pessoas de realizá-las ${ }^{31}$, ou - podendo as duas se conjugar - por causa de seu caráter espetacular, em uma lógica que se aproxima daquela do "sublime" e da "catarse" 32 .

\section{Fechar os olhos e abrir os olhos}

As questões levantadas pela posição ambígua e instável do aborto em relação ao campo da normatividade e seu distanciamento da esfera da representação levam a interrogações mais gerais referentes ao papel que a

\footnotetext{
${ }^{31}$ Ver o trabalho de Edgerton sobre o papel atribuído aos quadros das salas dos tribunais (Edgerton, 1985).

32 Ver Boltanski (1993).
} 
sociologia deve reconhecer à tensão entre o que é aparente e o que é velado, entre o que é explícito e o que é tácito, entre o que se olha facilmente de frente e aquilo a que se fecham os olhos, e o lugar que ela deve conceder a noções como "má fé", "ilusão", até mesmo "inconsciente". Sabe-se que tais noções são problemáticas porque seu emprego frequentemente deixa entender que haveria uma assimetria insuperável entre um agente social equivocado e um sociólogo em posição de observador onisciente, único capaz de romper com a ilusão e desvelar as realidades ocultas. Os principais defeitos desse tipo de posição epistemológica são, de um lado, levar à busca de um equivalente geral subjacente (como os "interesses" ou as "relações de força") capaz de explicar ao mesmo tempo as condutas dos atores e sua cegueira e, de outro, deixar o pesquisador pouco atento às competências dessas próprias pessoas para formar juízos e fazer críticas. Razão da exigência metodológica inversa de ficar o mais próximo possível do que dizem as pessoas e de levar a sério suas justificativas, suas críticas e, mais geralmente, as exigências morais que elas invocam ${ }^{33}$.

No entanto, uma assunção tão radical quanto à distinção entre um agente equivocado e um analista esclarecido opera uma passagem, em última instância, absolutamente desnecessária. A existência de uma correspondência imprecisa, vaga - ou, digamos, de uma defasagem - entre o que é publicamente acentuado e o que se busca ignorar pode ser destacada a partir das descrições e relatos dos atores a quem, aliás, ela não escapa na maioria das vezes, mesmo que o que se prefere não ver ou não ressaltar tenha nesses relatos um caráter residual. Mais precisamente, enquanto a apresentação do que tem status de um saber público pode facilmente assumir uma forma sistemática e geral (principalmente porque pode se apoiar em dados igualmente inscritos em formas de generalidade, tais como os estatísticos), o que é melhor ignorar se mostra como incidente, fortuito, secundário, circunstancial, isto é, como uma anedota.

Como se opera a distribuição das asserções entre esses dois modos de conhecimento? Propomos a ideia de que ela é tanto idealista, orientada para ideais morais, quanto eminentemente realista, ou seja, é uma função do engajamento na ação. Aquilo que é melhor ignorar é, primeiramente, o que se desaprova ou, no mínimo, o que se julga não ser um bem, mesmo não

${ }_{33}$ Cf. Boltanski (1990, particularmente a primeira parte: "Ce dont les gens sont capables", p. 37-63). 
podendo mudá-lo; sendo mais preciso, pressente-se que os esforços para mudá-lo fariam mais mal do que bem. Portanto, a defasagem entre o oficial e o oficioso, entre o que é bom dizer e o que é melhor calar, se deveria mais a uma idealização de certas formas do bem e a uma hierarquização implícita de diferentes tipos de males, que leva a optar por uma lógica do menor mal, do que a um diferencial de informação (embora, de tanto não querer ver, se acabe ignorando realmente aquilo que se evita), de conhecimento ou de consciência. Isso vale, particularmente, para todas as situações que encerram uma contradição cuja explicitação levaria a reconsiderar uma ordem social com a qual, por uma razão ou outra (inclusive razões atinentes a efeitos de dominação), se mantém uma ligação (apesar de seus defeitos considerados “inevitáveis”), para mudá-la mais ou menos radicalmente, (o que, quase sempre, parece impossível ou pior do que o mal que se busca curar), ou para enfrentar sua própria impotência e a ambivalência de seus próprios desejos.

Vista sob essa ótica, se assimetria há em favor do pesquisador, ela se deveria essencialmente - além de ele dispor, enquanto profissional, de mais recursos e principalmente de mais informações do que cada ator tomado separadamente - ao fato de que ele pode se apoiar nesse espaço reservado de um laboratório, pensar e agir como se pudesse colocar entre parênteses a referência a valores - sem se inquietar demais com o bem ou o mal - e como se pudesse se retirar do campo da ação. Então, na medida em que o pesquisador, neste caso, o "sociólogo", ocupando uma posição profissional muito particular e, sem dúvida, muito específica às sociedades liberais em suas formas contemporâneas, pode levar a reconhecer como legítima a ficção de que teria o direito de se liberar das urgências práticas, isto é, o direito de pensar de um modo considerado com razão como irresponsável por qualquer outro ator diretamente envolvido na ação, ele pode decidir colocar no mesmo plano o oficial e o oficioso, confrontá-los e também levantar contradições para as quais não dispõe de nenhuma solução e que manipula como se - retomando uma expressão de Jeanne Favret-Saada falando da bruxaria (Favret-Saada, 1977) - não estivesse envolvido. Deve-se ainda observar que essa falta de envolvimento só é possível em contextos, em épocas e em relação a problemas cuja exigência de solução não se apresenta de modo muito dramático, muito urgente ou não leva a conflitos violentos demais e, mais geralmente, em situações em que esses problemas não se mostram absolutamente insuperáveis. Pode-se então transpor às questões levantadas pela 
tensão entre o oficial e o oficioso, ou o destaque às contradições, as observações de Ian Hacking acerca dos projetos desconstrucionistas: é quando uma crença começa a se atenuar ou que se delineia a possibilidade de mudar uma prática que um grande número pesquisadores preocupados em empreender a desconstrução se apresenta (Hacking, 2001).

\section{As ciências sociais e a questão do engendramento}

Nós nos orientaremos agora pela ideia de que as duas propriedades do aborto que acabamos de estabelecer - ambiguidade em relação à normatividade e distanciamento da representação - devem, para se tornar inteligíveis, ser relacionadas a tensões mais gerais do engendramento, isto é, a criação de seres humanos novos que vêm tomar lugar em um mundo povoado por seres vivos e habitado pela lembrança dos mortos. Nossa hipótese é de que, atenuadas nas modalidades usuais da procriação, da gravidez e do nascimento, essas tensões se manifestam, em situação de aborto, com uma força particular e sob a forma de uma contradição que se torna então patente e, assim, mais dificilmente tolerável.

Nos próximos parágrafos, deixaremos então provisoriamente de lado a questão do aborto para nos deter naquela, mais geral, do engendramento. Lembraremos, de início, os diferentes modos como as ciências sociais consideram em geral essa questão, o que nos levará a colocar em primeiro plano uma dimensão do engendramento frequentemente negligenciada ou subestimada - a exigência de produzir seres suscetíveis de serem singularizados.

As ciências sociais não deram, em nossa opinião (seguindo o exemplo da filosofia), a atenção que a criação dos seres humanos merece. Esse esquecimento provavelmente se deve ao fato de que os filósofos, como fundadores das ciências sociais, foram, até um passado recente, quase exclusivamente homens. Mas, no caso das ciências sociais e particularmente da sociologia, deve-se também levar em conta o papel desempenhado por duas oposições classificatórias na constituição dessas disciplinas, cujo acesso ao status de "ciências" foi subordinado à dupla exigência de autonomia (os sistemas de causalidade pertinentes devem ser internos - por exemplo, é preciso "explicar o social por meio do social") e de generalidade (com o ideal de formulação de leis extraídas das circunstâncias nas quais elas se aplicam). No caso do engendramento, essas oposições levaram tanto a distinguir entre o "biológico" e o "social" quanto a destacar a oposição entre o "individual" e o "coletivo". 
Duas disciplinas dividiram entre si o canteiro da "produção" ou, retomando o termo geralmente utilizado, da "reprodução" dos seres humanos: a demografia, que se ocupa de fenômenos considerados essencialmente biológicos para estudar, com métodos matemáticos, seus efeitos sobre a sociedade, e a sociologia, que, buscando se independentizar mais claramente da Biologia, estabelece como meta estudar o que a sociedade faz com os recém-nascidos que lhe fornece a biologia, como eles são "socializados".

A demografia, cujo progresso está ligado ao da estatística, da economia e da higiene pública e, de modo mais geral, à consideração pelo Estado, a partir do século XVIII, dos problemas relativos à gestão biológica das populações de um território, muniu-se de conceitos globais, suscetíveis de serem aplicados tanto a coletivos humanos quanto a coletivos animais, como os de fecundidade, de mortalidade ou de população ${ }^{34}$. Preocupada em dar uma contribuição aos problemas de gestão global e de prospectiva que o Estado afrontava, a demografia abordou a questão do engendramento em termos de controle, com o objetivo de obter a população ótima, seja em termos de quantidade (declínio demográfico, superpovoamento, substituição das gerações, etc.), seja em termos de qualidade (degenerescência, seleção, hereditariedade, etc.).

Esse ponto de vista é encontrado nos raros estudos referentes ao aborto. Nas ciências sociais contemporâneas, foram, de fato, essencialmente os demógrafos e os especialistas em demografia histórica em particular que se interessaram pela prática do aborto nas sociedades tradicionais (na maioria das vezes, na esteira de estudos sobre a concepção). Essas pesquisas, que visam a resultados quantitativos, são muito difíceis e muito incertas pelas razões que mencionamos acima (raridade das fontes etc.). Nesse âmbito, a questão levantada foi especialmente a do controle, nas populações tradicionais antes do século XVIII, da quantidade de população. O princípio de explicação evocado para justificar o aborto é de ordem funcionalista. $\mathrm{O}$ aborto seria uma das práticas (juntamente com a contracepção, o atraso na idade do casamento, etc.) de que se serviram as sociedades para controlar o volume e, segundo alguns estudos, a qualidade de sua população.

Embora não rejeitemos completamente essas explicações funcionalistas, consideramos que elas determinam apenas perfis secundários do aborto,

34 Ver Foucault (1976, p. 35 ss., 179 ss). Ver também Le Bras (2000). 
mas não tocam no essencial (retomando o exemplo do casamento, o fato de que a idade no casamento possa ser manipulada para regular o volume da população não diz nada sobre a instituição do casamento em si). Por outro lado, deve-se observar que a noção de população, no sentido demográfico, é recente e está ligada à introdução progressiva nas esferas administrativas e políticas dos Estados ocidentais, sobretudo a partir do século XVII, de preocupações médicas e higienistas (que Michel Foucault designa sob o termo de "biopolíticas"), de modo a explicar o aborto pela vontade de controlar o volume da população global de uma sociedade constitui um anacronismo, ao menos quando se fala das sociedades antigas ou das sociedades estudadas pela antropologia. Excetuando o Estado moderno, apoiado em uma legitimidade "científica", não há ator histórico em posição de dominância e de poder capaz de sustentar o projeto de controlar em vasta escala, espacial e temporal (a regulação do volume de população supõe a criação de medidas que se estendem por várias dezenas de anos), o número e, mais ainda, a "qualidade" dos seres humanos sob uma mesma autoridade.

Já a sociologia, tomando a socialização como objeto de predileção, interessou-se particularmente pelo modo como as sociedades ou os grupos se encontram "reproduzidos". Nessa ótica, ela deu importância às crianças, principalmente porque são objeto de uma educação e, sobretudo, de uma formação escolar. Fazendo isso, corroborou, pelo menos implicitamente, a divisão entre uma produção da criança enquanto ser de carne, cujo estudo tangeria essencialmente às disciplinas biológicas e médicas, e uma formação da criança, enquanto objeto do social após seu nascimento, ou seja, como futuro membro de um grupo ou futuro cidadão, que a sociologia poderia, por essa razão, tomar como objeto de estudo. Esse ponto de vista, inspirado por uma concepção estrita da separação entre natureza e cultura, é visto, por exemplo, no caso dos estudos sociológicos, bastante recentes, sobre as interações entre crianças pequenas que, não encontrando na disciplina os instrumentos apropriados, foram buscar quadros conceituais e métodos na etologia animal.

Foi a partir da antropologia social, disciplina centrada em sociedades ditas “tradicionais", em que a separação entre a vida pública e a vida familiar não tem a mesma rigidez dos Estados modernos, e, particularmente, desde as correntes da antropologia culturalista que acolheram preocupações vindas da psicanálise, que a sociologia se interessou pela socialização das crianças 
via primeira educação familiar ${ }^{35}$. Porém, também nesse caso, foi dominante uma problemática da socialização na medida em que engaja a reprodução dos grupos já constituídos. O trabalho da sociologia consistiu então em mostrar (inspirando-se no modelo da socialização linguística) como os grupos se apropriam desse material, tratado como socialmente amorfo e polivalente - a criança que acaba de nascer - para lhe dar uma forma específica que, apesar da existência de variações individuais, poderá ser determinada em todos os membros de um mesmo grupo que, participando de uma mesma cultura, terão assim uma "identidade social" similar. O que interessa prioritariamente à sociologia é, portanto, o fato de que os seres humanos pertencem a categorias (étnicas, sociais, etc.) e são objeto de operações que os ligam a classes, quer sofram sua ação passivamente ou, aplicando sua reflexividade, busquem manipular as classificações que lhes dizem respeito ou que tangem àqueles com que eles mantêm relações determinadas (o que Pierre Bourdieu chama de "lutas de classificação").

\section{O estabelecimento das identidades singulares}

Cada uma dessas duas abordagens - mais demográfica ou mais sociológica - tem sua esfera de pertinência. $O$ número dos seres humanos ou sua qualidade (que hoje em dia não é mais considerada em termos biológicos, mas em termos de aptidões ou de competências resultantes de uma formação - de "capital humano") são certamente variáveis importantes quando se trata de considerar o envolvimento dos Estados na guerra ou na concorrência econômica. $\mathrm{O}$ fato de que os seres que pertencem à espécie humana possa ser objeto de uma educação que lhes confere uma forma específica e o fato, indissociável, de que, assim "socializados", sejam objeto de classificações, do mesmo modo que a existência de classes que se perpetuam apesar da mudança, devido à partida ou à morte dos indivíduos que fazem parte delas - recém-chegados vêm ocupar os lugares vazios deixados pelos antigos ocupantes nos grupos ou nas instituições - constituem sem nenhuma dúvida fenômenos fundamentais que ocupam o centro da sociologia.

De fato, os seres humanos em sociedade devem poder ser distribuídos no gênero de conjunto chamado de categorias ou classes. Um ser inclassificável é um ser associal. As classes repousam sobre um princípio de equivalência (que

35 Ver Boltanski (1969). 
pode ser explícito ou tácito) que permite dizer: sob esta ou aquela relação, este indivíduo é equivalente àquele outro. Elas repousam, assim, em uma metafísica de dois níveis: um deles compreende os espécimes empíricos, e o outro compreende o critério ou os critérios que os relacionam. Na medida em que se sustentam em propriedades, ou em combinações de propriedades (ou que se polarizam em torno de polos arquetípicos, como no modelo de Rosch ${ }^{36}$ ), as classes definem lugares que podem ser ocupados simultânea ou sucessivamente por diferentes indivíduos. São, portanto, relativamente independentes dos indivíduos que as compõem. Relativamente significa que elas não se confundem com os indivíduos (se assim fosse, os indivíduos poderiam pertencer a elas), mas que não podem existir por muito tempo sem um membro, de sorte que seja de certo modo ilustrado o princípio de ordem que as define. Uma classe ou uma categoria que não tivesse nenhum exemplo vivo cairia rapidamente em desuso. As pessoas são assim constituídas socialmente por seu pertencimento a classes, que elas reproduzem, exemplificando-as e representando-as. Enfim, a existência dessas categorias ou dessas classes é tanto mais manifesta porque elas possuem uma dimensão institucional, isto é, são dotadas de um caráter objetivo (independente do reconhecimento que lhes é atribuído), concretizado por sua ancoragem em coisas, sinais, códigos, direito, etc. O que se mantém no tempo, portanto, de uma geração à outra, apesar da mortalidade dos indivíduos, são precisamente essas classes que podem ser (ou não) "reproduzidas" conforme novos indivíduos venham (ou não) ocupar os lugares que elas encerram.

\section{A produção social das singularidades}

Todavia, essas duas perspectivas - os seres humanos tratados como membros de uma espécie e os seres humanos considerados enquanto pertencentes a grupos e objeto de classificações - são insuficientes. Existe um outro ponto de vista, que essas perspectivas deixam de fora e que consiste em considerar os humanos em sua singularidade. A referência à singularidade tem, nas ciências sociais, má reputação porque foi frequentemente e, em geral de maneira ingênua, utilizada precisamente contra as ciências sociais e

\footnotetext{
${ }^{36}$ Estudando a estrutura das categorias mentais, Eleanor Rosch mostrou como, diferentemente das categorias que figuram em nomenclaturas científicas, as categorias mentais não deviam ser concebidas como espaços homogêneos margeados por fronteiras, mas em termos de pontos focais e de periferia, com bordas imprecisas. Ver Rosch (1997, p. 212-222).
} 
para contestar sua pertinência ou denunciar seu caráter “inumano", o que só reforçou a hostilidade dos sociólogos contra esse tema, visto como marcado por preconceitos irracionais e espiritualistas, ou elitistas e "burgueses" 37.

Sendo assim, as ciências sociais, particularmente a sociologia, deixaram escapar um processo que deveria tê-las interessado acima de tudo, não porque ele viria contradizer os princípios sobre os quais se fundamentam essas disciplinas, mas, ao contrário, porque possibilitaria aprofundá- $\operatorname{los}^{38}$. $\mathrm{O}$ fato de ser singularizado é efetivamente uma particularidade muito geral, talvez a mais geral, dos seres humanos em sociedade. Não há, seja qual for o contexto societário de inscrição, quem não tenha um nome (ou vários) que não lhe seja $(\mathrm{m})$ próprio(s). Não há sociedades em que os ocupantes sucessivos de um mesmo lugar (na hierarquia social, por exemplo) não sejam pessoalmente identificados, diferenciados uns dos outros e, com frequência, comparados uns aos outros. A comparação supõe claramente que há uma convenção de equivalência sem a qual nenhuma taxionomia poderia se manter. Mas, para que a equivalência permita aproximar seres humanos sob um certo aspecto, é preciso que esses seres sejam identificados de maneira rígida, isto é, seja qual for a relação sob a qual são considerados ou, retomando uma formulação do livro De la justification (Boltanski e Thévenot, 1991), seja qual for o mundo em que são objeto de uma qualificação ou de um julgamento.

Os seres humanos que vivem em sociedade, necessariamente inscritos em diferentes taxionomias, devem igualmente poder, portanto, ser identificados como indivíduos singulares. Eles são então qualificados em relação a um conjunto do qual são o único membro. Não basta que sejam espécimes de uma espécie (a espécie humana) ou membros de diferentes categorias, que os apreendem levando em conta uma de suas propriedades (ser um tio, pertencer a tal ou tal subgrupo, ou, em nossa sociedade, a esta ou aquela profissão ou esta ou aquela classe social etc.) para assumir um lugar na sociedade de seus semelhantes. Cada um deles deve igualmente constituir um ser singular, quer dizer, um ser único de tal forma que nenhum outro possa

\footnotetext{
37 Sobre a relação no mínimo difícil que as ciências sociais mantiveram com a questão da singularidade, ver Heinich (1998).

${ }^{38}$ Observemos, todavia, que há um grande livro das ciências sociais e que trata dos processos sociais de formação da identidade individual e de manifestação da singularidade. Trata-se da obra que Béatrice Fraenkel dedicou à história da assinatura (Fraenkel, 1992). Nesse trabalho, Béatrice Fraenkel mostra notadamente como a assinatura, que leva, através do gesto de onde procede, a marca do corpo próprio daquele que assina, acabou confirmando duradouramente os contratos na ausência dos contratantes e até na ausência das testemunhas, representando o papel de um substituto duradouro da presença.
} 
substituí-lo e pretender ser exatamente o mesmo. Enquanto pertencente a uma classe, um indivíduo pode evidentemente substituir outro indivíduo da mesma classe em uma função, um papel ou um lugar aberto aos membros dessa classe. No entanto, será considerado evidente que ele não é o mesmo e que essa diferença é insuperável (e seguidamente se considerará também que ele pode realizar mais ou menos bem do que um ou outro a função que ele ocupa, mas que não pode ocupá-la sem lhe dar um toque pessoal). Nesse sentido, pode-se dizer - e isso em um registro positivo e não em um registro ético - que cada indivíduo é, por essa razão, insubstituível, mesmo que múltiplos processos sociais assegurem a permanência das instituições e classes, permitindo a diferentes singulares ocuparem simultânea ou sucessivamente um ou mais lugares definidos como idênticos ou similares.

A identificação dos seres humanos enquanto singulares constitui um fenômeno cujo caráter universal foi, em larga medida, ignorado pelas ciências sociais $^{39}$, porque a singularização foi confundida com outro processo, particularmente desenvolvido nas sociedades ocidentais modernas, que é a individuação. O grau no qual os seres humanos são considerados prioritariamente como indivíduos, ou seja, enquanto seres autônomos detentores de direitos subjetivos ou, ao contrário, enquanto pertencentes a coletivos com os quais compartilham os direitos, os deveres e o destino, é certamente muito desigual conforme as sociedades. Resta, entretanto, que, mesmo nas sociedades consideradas "holistas", não há ser humano do qual se possa dizer que pertence plenamente ao seu mundo (ao invés, por exemplo, de apenas constar como "coisa”) e cujo caráter singular não seja explícita ou tacitamente reconhecido. Pode-se então afirmar, sem grande audácia, que não há sociedade em que os seres humanos não passem por um processo de singularização que lhes atribua um nome ou vários que os designem pessoalmente e um lugar único em um conjunto ordenado (na maioria das vezes, em um sistema de parentesco).

Ora, essa singularização dos seres humanos não é um processo que se daria fora do social ou contra ele (como quando se opõe, ao lançar frequentemente um olhar crítico sobre as ciências sociais, a singularidade como qualidade do sujeito "autêntico", suscetível de resistir à pressão do social, ao "conformismo"

\footnotetext{
${ }^{39}$ Com exceção - caso se admite considerá-la como uma "ciência social" - da psicanálise que, desde o início, se dotou de instrumentos para fazer o vaivém entre a constituição de um arcabouço geral e a atenção às manifestações pelas quais as pessoas se revelam no que têm de mais particular, especialmente, por causa do caráter particular de cada percurso biográfico.
} 
que caracteriza aquele que se encontra passivamente submisso ao social instaurado). A singularização é, ao contrário, uma operação que se dá na vida social. Tratando-se da questão da identidade, a sociologia não deve, então, se limitar a descrever os processos de formação da "identidade social”, ou seja, as modalidades, bem reais, segundo as quais indivíduos diferentes reconhecem ter algo de essencial em comum já que compartilham um mesmo modo de vida e o pertencimento a um mesmo grupo ou a uma mesma classe, cujos traços taxionômicos pertinentes são incorporados a símbolos aos quais eles podem "se identificar". A sociologia deve também enfrentar a questão da identidade pessoal e tomar como objeto os processos pelos quais cada ser humano se encontra pessoalmente identificado, sem que seja possível confundi-lo duradouramente com outro.

Pensamos que é tomando como objeto os atos de engendramento, responsáveis pela chegada ao mundo social de seres humanos novos, que se pode encontrar um caminho de acesso aos processos de singularização. Mas isso supõe renunciar à ideia de que o trabalho da sociologia começaria com o estudo da socialização e da educação primária, como se os recém-nascidos fossem seres socialmente amorfos que a biologia forneceria à sociedade para que ela se apropriasse deles e os sociabilizasse ${ }^{40}$. De fato, em nossa opinião, é durante um processo contínuo, que vai da concepção à integração em um grupo social, passando pela gravidez e pelo nascimento, cuja gestação (no entanto relativamente pouco estudada pela sociologia até pouco tempo atrás) constitui uma etapa particularmente importante, que se inicia a singularização dos seres humanos, que terá continuidade nos diferentes momentos da socialização.

Para encontrar elementos que permitam avançar nesse caminho, devemos nos voltar para uma outra disciplina: a antropologia social. Com efeito, foram os antropólogos que, por um lado, deram mais atenção aos atos de engendramento e às concepções da geração desenvolvidas em sociedades diferentes das nossas; por outro lado, eles descreveram com muito cuidado os modos de socialização das crianças (esses dois desenvolvimentos foram estimulados pelo encontro da antropologia com os estudos femininos, que permitiu ir além do

\footnotetext{
40 A sociologia, considerando que a socialização opera sobre um recém-nascido tratado como um substrato amorfo e, de certa maneira, dado pela espécie à sociedade, queria primeiro lutar contra as concepções que pretendiam estabelecer a existência de grupos sobre uma base biológica e que, por consequência, pretendiam deduzir as propriedades comuns aos membros de um grupo do pertencimento a uma mesma raça, a partir de um modelo derivado daquele espontaneamente elaborado pelos criadores, no caso dos animais domésticos.
} 
ponto de vista propriamente masculino sobre a criança como membro virtual da sociedade política ${ }^{41}$ ); enfim, foram os mais atentos aos processos sociais de singularização dos seres humanos. Na antropologia, como na sociologia, a questão da singularidade não é abordada diretamente. Ela abriu o caminho, no entanto, por meio de duas questões intrinsecamente ligadas, que tiveram um papel muito importante na história dessa disciplina, a do parentesco e a dos nomes próprios, cuja atribuição é objeto de regras variáveis de acordo com as sociedades. Através desses dois tipos de problemas, a consideração da singularidade nasceu indiretamente do interesse pelos processos de classificação.

Em relação à questão do aborto, o interesse da literatura da antropologia social (disciplina que, como vimos, nem sempre a abordou de forma direta, pelo menos no aspecto teórico) por nosso objeto é não destacar somente a questão quantitativa do volume da população e de seu controle, mas também os problemas que se referem ao vasto domínio do simbólico e, particularmente, ao parentesco como sistema de relações simbólicas. Esse deslocamento é essencial para distinguir bem uma problemática da reprodução da espécie humana e uma problemática centrada na questão da criação de seres humanos novos e de sua inserção em coletivos que lhes preexistem.

Daremos aqui dois exemplos da maneira como a antropologia aborda a questão da singularidade a partir do estudo das relações de parentesco e daquele sobre a relação entre termos classificatórios e nomes próprios.

\section{Singularidade e parentesco}

O vasto domínio do parentesco está na conjunção de dois conjuntos de fatos que podem ser objeto de uma distinção analítica. Os primeiros são relativos à reprodução dos seres humanos e, por consequência, das sociedades humanas. Os segundos dizem respeito aos sistemas, aos termos e às relações de parentesco. A questão levantada pela relação entre reprodução e parentesco é geralmente relacionada ao problema da articulação do "biológico" e do "social". No caso da espécie humana que, como as outras espécies vivas, é submetida às imposições biológicas do nascimento e da mortalidade, de modo que deve se reproduzir para continuar existindo, como essa função de reprodução deve ser organizada para que se desenvolvam essas formas coletivas, associadas a modos específicos de coordenação, que chamamos de

${ }_{41}$ É bastante recente a afirmação de disciplinas como a antropologia do nascimento e a antropologia da reprodução, cujo desenvolvimento deve muito, sem dúvida, à feminização da profissão de antropólogo. 
"sociedades"? A resposta habitual a essa pergunta é que são as imposições do parentesco que, sobrepondo-se às imposições da reprodução, asseguram a subordinação do "biológico" ao "social". Nessa lógica, a sexualidade, da qual depende a reprodução, se encontra enquadrada e imposta pelo parentesco, que transforma assim um fenômeno biológico em processo social.

As imposições de parentesco, organizadas em sistemas, são geralmente ordenadas em dois eixos: o eixo da filiação e da descendência e o eixo da aliança ${ }^{42}$. O eixo da filiação "é aquele que define e memoriza de quem provém o indivíduo". Ele vincula um indivíduo particular a um número mais ou menos considerável de ascendentes ${ }^{43}$. Quanto ao eixo da aliança, "ele estabelece com quem um indivíduo pode se unir" ou, quando o sistema é prescritivo, com quem esse indivíduo deve se unir.

Desde o lançamento das Estruturas elementares do parentesco, de Claude Lévi-Strauss, a questão da filiação foi largamente subordinada à da aliança. A exigência de uma aliança realizada fora da família, concebida como uma unidade de ordem biológica (rejeição do incesto), está associada à necessidade da troca, da dádiva, da dependência mútua, da circulação. O que está em jogo aqui é a coesão de coletivos mais ou menos extensos de seres humanos que, devido à sua diferenciação relativa (inscrita nas estruturas de parentesco) e à sua dependência mútua, se encontram associados, de modo que as relações de concorrência violenta, pela guerra entre unidades de pequeno tamanho (que podem se transformar em uma guerra de todos contra todos), são substituídas por relações mais pacíficas, que abrigam concorrência e cooperação ${ }^{44}$. Portanto, seria a necessidade da aliança, ou seja, da constituição

\footnotetext{
42 Descrevemos esses fundamentos do parentesco a partir de Godelier e Hassoun (1996, p. 36-37).

${ }^{43}$ Nem todos esses ascendentes têm o mesmo "peso de parentesco" e não estão, com esse indivíduo, em uma mesma relação de descendência, que depende do sistema: patrilinear (descendência pelos homens), matrilinear (descendência pelas mulheres) ou cognático (descendência indiferenciada).

${ }^{44}$ Esse modelo se estende ao problema levantado pela coesão nas sociedades sem Estado (ditas "primitivas"ou "simples") das soluções propostas pela filosofia política e depois pela sociologia para explicar a coesão nas sociedades com Estado (ou"políticas"ou "complexas"). A questão de como é possível que os homens escapem da guerra de todos contra todos vem de Hobbes; a ideia de que a troca constituiria um substituto pacífico à guerra vem da filosofia política do século XVIII e, particularmente, de Adam Smith (ver Hirschman, 1980); enfim, a ideia de uma coesão que se operaria através da diferenciação vem de Durkheim, mesmo que Claude Lévi-Strauss a modifique profundamente, equivalendo a suprimir um dos termos da oposição durkheimiana (a solidariedade mecânica) de maneira a estender a solidariedade orgânica às sociedades ditas "primitivas" ou "simples". A coesão dessas sociedades, mesmo que não tenham levado muito adiante o desenvolvimento da solidariedade orgânica pela divisão do trabalho, não depende unicamente, no entanto, de uma solidariedade mecânica (por similaridade), já que as formas de diferenciação que dizem respeito ao parentesco suscitam uma dependência que se exprime pacificamente na lógica da troca.
} 
de coletivos de um tipo particular cuja coesão seria assegurada por meio da troca entre segmentos diferenciados, mas dependentes (o que os distinguiria nitidamente dos coletivos animais), a marca principal do "social".

Quanto à questão da perpetuação dos coletivos humanos - ainda que sejam compostos por indivíduos mortais - (que, nas sociedades de Estado, está no coração da filosofia política), ela seria, nessa ótica, igualmente levada em conta pela lógica da aliança. Como cada segmento do coletivo estaria sempre em dívida com outro segmento e, portanto, à espera de um retorno, pode-se dizer, do "próximo golpe", a forma de coesão suscitada pelo parentesco, longe de ser instantânea, inscrever-se-ia em uma temporalidade e constituiria um processo contínuo mantido mutuamente. Nesse sentido, a lógica da aliança absorve a da filiação. Por conseguinte, o problema levantado à antropologia se torna essencialmente o da articulação do biológico ao social através da relação entre reprodução e aliança. Um substrato biológico comum às espécies vivas, aos mamíferos e aos primatas estaria, no caso dos humanos, imerso em um sistema de aliança, e dessa articulação nasceria o "social".

Descrito nesse nível elevado de generalidade, o estudo do parentesco não parece romper em nada nem com a premissa de uma separação clara entre o que é do domínio da "reprodução biológica", de um lado, e da "reprodução social", de outro, nem com uma abordagem de orientação classificatória. Notemos imediatamente, no entanto, que o parentesco pode ser objeto de dois tipos de descrições: uma descrição na lógica de um sistema, quando se submete os termos de parentesco a uma análise taxionômica, e uma análise que, acentuando as relações de parentesco, descreve-as sob forma de diagramas cuja origem (ego) é sempre um indivíduo singular. As questões que a correlação desses dois tipos de descrições levanta abrem caminho para uma problematização da singularização dos seres humanos.

Foi partindo das premissas que acabamos de lembrar muito brevemente -interdição do incesto e exigências da aliança - que Maurice Godelier, em Meurtre du père, sacrifice de la sexualité (Godelier e Hassoun, 1996, p. 21-52) (obra escrita juntamente com o psicanalista Jacques Hassoun), construiu um roteiro visando unir a gênese da vida social e o processo de singularização dos seres humanos ${ }^{45}$. Godelier relaciona o processo de individuação com

${ }^{45}$ Esse roteiro ( Godelier o reconhece naturalmente), como todas as "histórias de origem" - tanto as de Rousseau e dos contratualistas quanto as que nos foram contadas por Freud ou Lévi-Strauss -, apresenta um caráter hipotético, até mítico, mas permite lançar luz sobre uma dimensão fundamental da existência social. 
a instituição do parentesco, a qual ele associa, seguindo os passos de Lévi-Strauss, à renúncia a tomar uma mulher no círculo próximo da família e, por consequência, ao "sacrifício" de uma forma de expressão da sexualidade que aparece ao longo da evolução dos primatas ao homem. Essa sexualidade livre de certas imposições biológicas que pesam sobre os primatas (especialmente a menorréia) é "polimórfica" e "politrópica". Ela "funciona" no "imaginário" e pode incidir sobre qualquer ser" ${ }^{46}$. "desejo" fica "desatrelado parcial ou completamente do processo da reprodução da espécie" (p. 29). Imperativa, fundamentando sua realização na força, tal sexualidade, que "não tem em si mesma sentido social" (p.30), é um fator permanente de violência, de desunião e de desordem (Godelier encontra aqui, por outra via, a história de origem contada por Freud). O "trabalho de domesticação" dessa sexualidade (Godelier fala ainda de "inflexão da sexualidade") se desenvolve no seio da família ao longo da primeira educação das crianças que, forçadas a renunciar a se apropriar sexualmente dos seres presentes em seu círculo familiar (pai, mãe, irmão, irmã, sejam eles membros de outro sexo ou do mesmo sexo, mas também animais domésticos), são assim incitadas a ir procurar no exterior objetos suscetíveis de saciar seus desejos sexuais (p. 34).

As "relações de parentesco" se desenrolam então "como uma rede de relações entre indivíduos dos dois sexos ou grupos de indivíduos", que supõe que "as relações dos indivíduos com os indivíduos dos quais eles provêm tenham sido identificadas e reconhecidas e que as relações entre essas relações sejam igualmente compreendidas". Enfim, "o conjunto das relações reconhecidas está sempre centrado em um ego abstrato, em um indivíduo que é caracterizado apenas por seu sexo, ou seja, que é definido como homem

\footnotetext{
46 Observemos que essa gênese mítica da memória e, dessa forma, da duração e de sua inscrição em uma história, através da passagem de uma sexualidade regulada pelas fases do ciclo menstrual a uma sexualidade suscetível de ser satisfeita sempre é delineada por Kant em Conjectures sur le commencement de I'histoire humaine. Enquanto em Rousseau a sexualidade não desempenha nenhum papel na passagem do estado de natureza à situação histórica, em Kant ela intervém através da recusa que, não sendo mais predeterminados os períodos em que a relação sexual é possível, pode sempre se opor aos desejos, que torna então mais intensos e que deriva para o lado da imaginação. É para superar a insaciabilidade suscitada pela recusa, diminuindo, através da sedução, as resistências que se opõem ao desejo que os artifícios da civilização são inventados (arquitetura, adorno) e que se opera um deslocamento dos atrativos sexuais aos atrativos ideais, que vai no sentido de uma "progressão no sentimento do belo e do sublime". Contudo, como a "sedução" feita para convencer as resistências da recusa pressupõe "a consciência da liberdade do outro", essa gênese mítica da cultura é também uma gênese mítica do direito e do reconhecimento (ver Philonenko, 1986, p.155-159). Agradeço a Éric Vigne que chamou minha atenção para o papel dado por Kant à sexualidade no processo de humanização.
} 
ou mulher e que, em todos os casos, se apresenta como o ponto de chegada e o ponto de partida de certo número de relações com outros” (p. 36-37).

Godelier desenvolve a ideia de uma ligação necessária entre a exigência de procurar objetos sexuais fora do círculo familiar - que está na origem do parentesco - e o processo de singularização dos indivíduos. Com efeito, diz o autor, se "a proibição de encontrar um parceiro entre os seus (...) se aplica geração após geração, então o indivíduo, como a sociedade, se encontram na obrigação de identificar e de memorizar o que lhe diz respeito e é idêntico a si e o que não é, de guardar a memória dos homens e das mulheres de quem cada um provém, identificando os indivíduos e os grupos com os quais se poderá ou deverá doravante se aliar" (p. 36). Em um mundo social, como o dos chimpanzés (que, diz Godelier, conforme os dados etológicos disponíveis, é próximo daquele que conheceu a "humanidade primitiva", p. 24), organizado em "bandos", sem divisão sexual do trabalho nem relações sexuais proibidas, o esforço da identificação dos singulares não teria nenhuma razão de ser levado além do que é necessário para manter um apego transitório entre um macho e uma fêmea e uma fêmea e seus filhotes.

Enfim, Godelier insiste em um processo que acompanha o estabelecimento das relações de parentesco e a singularização dos indivíduos, que é a disjunção parcial entre o que ele chama de "sexualidade desejo" e a sexualidade na medida em que assegura a reprodução da espécie (p. 29). O que está em jogo, com a instituição do parentesco e com a singularização dos indivíduos que a acompanha, não é a "reprodução biológica do homem”, que poderia ser igualmente realizada por uma sexualidade não "domesticada”, mas “a reprodução da ordem que deve reinar até certo ponto nas sociedades humanas para que exista sociedade" (p. 33). Doravante, a reprodução dos indivíduos que compõem a sociedade se encontra, de alguma maneira, desatrelada da sexualidade. A relação sexual continua, com certeza, necessária para fazer novos seres, mas a esses seres só está ligado um valor - no sentido linguístico do termo, mais do que no sentido econômico, já que esse valor é primeiramente distintivo -, na medida em que sua proveniência pode ser identificada e que, sendo julgada válida, lhes dê a possibilidade de ocupar um lugar singular identificável em um nó de relações. Significa dizer então que, no largo conjunto das relações sexuais almejadas não proibidas ( $\mathrm{e}$, em numerosas sociedades, realmente concretizadas, mas à margem das relações de parentesco, por exemplo, na adolescência), somente algumas delas podem ser selecionadas para assegu- 
rar, não a reprodução da espécie, que não está em questão aqui, mas o que se poderia chamar, para distinguir da reprodução biológica, de regeneração da sociedade, ou seja, o engendramento de seres suscetíveis de serem pessoalmente identificados e de ocuparem um lugar singular.

Notemos que a separação da sexualidade e do engendramento (que é uma consequência do que Maurice Godelier chama de inflexão da sexualidade), mesmo assumindo uma forma particularmente clara nas sociedades contemporâneas com o desenvolvimento, de um lado, das técnicas de contracepção (sexualidade sem engendramento) e, de outro, das técnicas de reprodução medicamente assistida (engendramento sem sexualidade), está longe de ser, como se lê por vezes, uma novidade radical. Pode-se até pensar que se trata de um horizonte para o qual tendem, com mais ou menos sucesso, a maioria das sociedades. George Devereux, em seu estudo sobre o aborto, desenvolve um tema bastante próximo daquele que acabamos de tomar emprestado do trabalho de Maurice Godelier, mas, de certa maneira, do ponto de vista dos atores. A partir notadamente dos trabalhos que consagrou aos índios mojave (mas buscando exemplos também em outras sociedades), Devereux dedica várias páginas ${ }^{47}$ à tensão entre o que ele descreve como dois usos radicalmente diferentes da sexualidade. O primeiro, que não é absolutamente orientado para o engendramento, leva a sexualidade para o lado não somente do prazer, precisamente no sentido sexual, mas, de modo mais geral, para o da brincadeira, da exploração, do excesso, da diversão, da excitação etc., em sociedades nas quais, na ausência - como diz de maneira um tanto cômica Devereux - "de teatro, de show, de cinema, de tevê e de saídas sábado à noite", a sexualidade constitui o principal remédio para o tédio. A esfera da sexualidade-diversão também é, diz o autor, nas sociedades em que as imposições da vida coletiva são muitas, quase a única esfera de "vida privada e individual". O segundo uso da sexualidade, ao contrário, de certa forma subjugado ao engendramento, acontece dentro das relações legítimas instituídas pelo parentesco, que, nas sociedades tradicionais, se encontra no centro das relações políticas (que se submetem às relações de aliança e de filiação), em um âmbito público. Dessa forma, é associado à seriedade, à responsabilidade, ao cansaço, às imposições coletivas, à frustração

\footnotetext{
47 Devereux (1996, p.111-125). A ideia que Devereux segue, na verdade (mas que não retomamos em nossa interpretação), é a de uma preeminência dos fatores contra-edipianos sobre os fatores edipianos. Pelas razões que acabamos de afirmar, a agressividade não somente do pai, mas dos pais em relação aos filhos menores, prevaleceria sobre a agressividade da criança pequena em relação a seu pai.
} 
(especialmente com os frequentes interditos sexuais durante a gravidez e amamentação). Se tal oposição distingue frequentemente uma sexualidade juvenil e uma sexualidade adulta, ela não se sobrepõe inteiramente, no entanto, com as faixas etárias, mas apresenta, em todas as idades da vida, alternativas relativamente antagonistas com as quais é preciso compor; de fato, devido a um tipo de fatalidade inerente ao destino da espécie humana, essa coisa divertida e da qual não nos cansamos que é a sexualidade se tornou também o apoio do desenvolvimento da vida social e, por consequência, da vida propriamente humana, resultando em uma posição de instabilidade bem desconfortável entre o contingente e o instituído, o jogo e o ritual, o instantâneo e o duradouro, o individual e o coletivo; entre o que há de menos sagrado e o que há de mais sagrado na vida cotidiana.

\section{Termos classificatórios e nomes próprios}

É também partindo do estudo das classificações e, mais precisamente, do desafio que os nomes próprios, por meio dos quais os seres humanos são identificados, parecem opor à lógica classificatória à qual obedecem geralmente as formas sociais simbólicas, que Claude Lévi-Strauss acaba substituindo a oposição clássica entre o que tangeria à ordem do geral (considerado o único objeto possível de ciência) e o que seria propriamente singular (abandonado à arte ou à literatura) por uma análise da passagem contínua entre esses dois modos de apreensão dos seres humanos em sociedade.

Em O pensamento selvagem $(1962)^{48}$, Lévi-Strauss, discutindo com o linguista Gardiner (que retoma a ideia de Bertrand Russell, segundo a qual o nome próprio seria uma etiqueta que designa um objeto particular e poderia assim ser oposto aos nomes de classe, que são predicados), pretende mostrar que sempre se pode transitar nos dois sentidos do nome de classe (comportando um número indefinido de espécimes) ao nome próprio. Os princípios de classificação podem ser postos em prática, ao preço de diferentes transformações, seja rumo a uma universalização, seja rumo a uma particularidade estendida até os nomes próprios. Disso conclui que não se pode opor à significação, que estaria em questão na lógica das classificações, uma outra operação, a nominação, que caracterizaria a lógica dos nomes próprios, pela qual seres seriam "nomeados porque não podem ser significados" (p. 226). Ele mostra, ao contrário, como a lógica classificatória pode ser estendida até

${ }^{48}$ Particularmente o capítulo VII: "Lindividu comme espèce". 
a individuação, de sorte que é sempre possível executar operações que permitam ir do nome próprio ao clã ou, o oposto, traçar o caminho inverso, do clã ao nome próprio (“... pode-se passar, com a ajuda de transformações, do horizonte de individuação ao das categorias mais gerais", p. 230).

Há, portanto, passagens entre os indicadores de classe e as marcas de identificação singular, desde que se veja nessas últimas maneiras de designar um "tipo de variedade" ou uma "espécie", ou seja, "uma síntese de ideias e de condutas tão insubstituível quanto aquela operada por uma espécie floral", existindo apenas no estado "monoindividual" (o que, acrescenta Lévi-Strauss, "não existe provavelmente na natureza..." ${ }^{49}$ ), de modo que essa "variedade" desaparece quando "uma personalidade morre". O nome próprio pode então ser considerado como um nome de classe que comporta apenas um único espécime, e isso sem mudar a lógica. Ele compreende os seres humanos a partir da ótica de que cada um deles pertence a um "tipo de variedade comportando apenas um único espécime", quer dizer, cada um deles é "incitado a desenvolver uma personalidade" que lhe confere um caráter "insubstituível” (mesmo que outros possam ocupar este ou aquele lugar que eles mesmos ocuparam $)^{50}$. Passa-se assim, sem solução de continuidade, de uma lógica classificatória, fazendo referência a classes cujos membros, substituíveis, têm

\footnotetext{
49 No entanto, há um animal, certamente mítico, que reúne em si mesmo as características do indivíduo e da espécie; é a fênix, como observa Fraenkel, citando Kantorowicz. É a razão pela qual Dignitas é comparável à fênix, da mesma forma que o selo real que, atualizando a "gemelaridade do sujeito real", personifica a coincidência "da espécie e do indivíduo". A comparação, escreve Kantorowicz, citado por Fraenkel, não era mal escolhida. Não havia nenhuma fênix viva ao mesmo tempo; cada nova fênix era idêntica à precedente e seria "idêntica” à seguinte. Além disso, no caso dessa ave - de certo modo semelhante aos anjos -, a espécie e o indivíduo coincidiam. "Toda a espécie está preservada no indivíduo", como salienta Balde, "assim cada fênix era ela própria toda a espécie fênix existente" (Kantorowicz, 1989, p.101, apud Fraenkel, 1992, p. 88).

50 É preciso citar aqui quase toda a página em que Claude Lévi-Strauss sintetiza essa diferença: "Essas precisões eram indispensáveis para nos permitir sublinhar, sem correr o risco de mal-entendidos, o caráter ao mesmo tempo sociológico e relativo que se liga à noção de espécie como à de indivíduo. Considerados sob o ângulo biológico, homens oriundos de uma mesma raça (supondo que esse termo tenha um sentido preciso) são comparáveis às flores individuais que brotam, se abrem e morrem na mesma árvore: são espécimes de uma variedade ou de uma subvariedade; da mesma forma, todos os membros da espécie Homo sapiens são logicamente comparáveis aos membros de uma espécie animal ou vegetal qualquer. Todavia, a vida social produz nesse sistema uma estranha transformação, pois ela incita cada indivíduo biológico a desenvolver uma personalidade, noção que não evoca mais o espécime no seio da variedade, mas preferencialmente um tipo de variedade ou de espécie que provavelmente não existe na natureza (ainda que o meio tropical tenha tendência por vezes a esboçá-lo) e que poderia ser chamada de "monoindividual". O que desaparece quando uma personalidade morre consiste em uma síntese de ideias e de condutas, tão exclusiva e insubstituível quanto a operada por uma espécie floral, a partir de corpos químicos simples utilizados por todas as espécies" (Lévi-Strauss, 1962, p. 284).
} 
uma identidade numérica, mas considerada secundária (ela pode, no caso dos pássaros, ser marcada por um número inscrito no anilho), a uma lógica dos nomes próprios, que reforça a singularidade de cada ser e seu caráter insubstituível, tratando-o como se fosse uma espécie. De fato, embora os indivíduos sejam substituíveis no interior de uma espécie, as espécies não podem, ao contrário, ser substituídas umas pelas outras (não se pode dizer que a espécie das toutinegras está extinta e que será substituída pela dos melros).

Longe de opor a classificação, que seria própria ao social, à singularização que lhe escaparia, essa análise visa, portanto, mostrar ao contrário que o processo de singularização constitui uma das operações possíveis que se apresentam ao pensamento classificatório. Ou, caso se queira, que é precisamente porque o surgimento de recém-nascidos, que é preciso nomear, levanta um problema ao sistema de classificação e o ameaça que o nome que se atribui a eles e que os singulariza comporta sempre "um elemento significante que pode se relacionar diferencialmente com outros elementos em um sistema de classificações ${ }^{51}$ ".

\section{Progressão para a generalidade e progressão para a singularidade}

Os dois exemplos que acabamos de recordar sugerem que o fato de pensar nos seres humanos sob a ótica da singularidade não é menos estranho às "ciências sociais" nem menos "científico" do que o fato de considerá-los enquanto pertencentes à espécie humana (uma tentação da demografia) ou sob a ótica de seu pertencimento a classes (o ponto de vista habitual da sociologia). Um erro (fundador) da sociologia, ditado sem dúvida por sua preocupação em se aproximar das ciências positivas e se afastar da filosofia, foi ver a marca do social na incorporação por membros substituíveis nas classes compostas, quando não era, sob a influência de um reducionismo inspirado na maneira como ela compreendia a biologia, estabelecer como objeto de predileção o pertencimento à humanidade como espécie, descartando do social os processos de singularização, como se a existência dos indivíduos enquanto seres singulares (frequentemente, aliás, concedida com desdém quando não simplesmente contestada como ilusão "idealista" ou "espiritualista") não fosse de sua competência ${ }^{52}$.

\footnotetext{
${ }^{51}$ Frédéric Keck, "Individu et personne dans La pensée sauvage de Lévi-Strauss", texto inédito. Agradeço a Frédéric Keck, que chamou minha atenção para o texto de Lévi-Strauss e para as distinções que ele estabelece.

52 Uma posição tão obstinadamente contrafatual não deixou, aliás, de suscitar reações igualmente contestáveis que, a partir da mesma oposição (a sociedade versus o indivíduo singular), levaram a projetos
} 
A maneira como a vida social molda a condição humana consiste de um vaivém constante entre a generalização e a singularização: o pertencimento de seres à humanidade é reconhecido; são reunidos em classes de equivalência, de acordo com traços, explícitos ou implícitos, suscetíveis de revelar entre eles semelhanças tais que, apreendidos sob determinado aspecto, possam ser considerados como relativamente substituíveis; mas são também, e pela mesma operação, singularizados, de sorte que cada um deles, enquanto ele próprio, não possa ser substituído por nenhum outro. É ao caráter "rígido" (retomando o termo empregado por Saul Kripke quando fala de "designado-

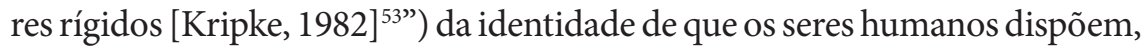
que os segue através de sua atribuição a diferentes classes ou sua passagem em diferentes mundos (em particular no sentido em que empregamos esse termo em De la justification), que os nomes próprios fazem referência. Pode-se pensar, aliás, que, sem a existência de tais formas de identificação rígida, a atribuição a classes e a travessia dos mundos se revelariam muito rapidamente insustentáveis devido à impossibilidade de articular e coordenar as diferentes dimensões da existência social, ou - retomaremos esse tema posteriormente - de reconhecer um mesmo indivíduo em um sujeito dotado de um corpo humano quando encontrado sucessivamente em mundos diferentes (mais ou menos como quando, cruzando com alguém por acaso, o reconhecemos, mas sem sermos capazes de identificá-lo - de "saber quem é" - porque se trata de uma pessoa que estamos habituados a encontrar em determinado contexto, na mercearia, por exemplo, e que de repente vemos em outro contexto, em um concerto de Mahler).

Observemos, de passagem, que, para descrever as operações que permitem transitar nos dois sentidos, do mais geral ao mais singular e do mais singular ao mais geral, convém evitar a metáfora, que parece contudo natural para um intérprete habituado à lógica do direito ocidental, da verticalidade, como quando se fala em "progressão para a generalidade", a partir de uma

visando enfatizar outro termo. Elas assumiram frequentemente a bandeira da noção de "pessoa" em uma acepção (uma versão fraca da tradição kantiana) carregada de valores morais de "autonomia"e de "responsabilidade". Poder-se-ia então opor a "autonomia" e a "responsabilidade" do "sujeito" como "pessoa" ao "conformismo" do "coletivo", o que abriria evidentemente a via ao contra-fogo fácil consistindo em desvelar os preconceitos de classe subjacentes a essa versão (a "elite" contra a "massa") da oposição entre "indivíduo" e "sociedade" e "sociedade", e assim por diante.

53 Tradução para o francês de Pierre Jacob e François Recanati de Naming and necessity, publicado primeiramente nos Estados Unidos em 1972; republicado em 1980. 
singularidade que lhe seria inferior (ou subjacente) sob um ângulo quase espacial. Essa metáfora sugere efetivamente a ideia, comum à filosofia política ocidental e largamente retomada pela sociologia (nós mesmos já a utilizamos com frequência), de que os singulares seriam de certo modo elementos de "base", "tijolos", que se deveria juntar para "passar" do "individual" ao "social", construindo "coletivos" concebidos como entidades de nível mais geral e, mais precisamente, como classes de equivalência, permitindo reunir os elementos singulares e lhes dar uma coesão. Tal metáfora, que tem seu fundamento na construção do Estado moderno, supõe, portanto, que os elementos de base, os "tijolos", ou seja, os singulares, sejam menos "sociais" e, ao menos implicitamente, estejam mais próximos de um estado biológico, até animal, da humanidade, do que as entidades gerais o estariam, os "coletivos" no seio dos quais se encontram incluídos. Ora, a singularidade de cada ser humano tomado individualmente não é menos criação da sociedade do que o são as classes de equivalência nas quais esses singulares podem se encontrar integrados. Portanto, é tão justo, mas de outra perspectiva, falar de "progressão para a singularidade" do que de "progressão para a generalidade" (Heinich, 1998, p.47).

Apresentaremos agora um esboço de modelo do engendramento que focaliza a questão de como os seres humanos são, desde sua criação, não somente destinados a classes, mas também dotados de uma singularidade. Para delinear esse modelo, adotaremos um comportamento de aspecto gramatical, no sentido de levantarmos a questão das imposições que pesam sobre a ação que consiste em introduzir seres humanos novos que virão ocupar lugar em um mundo social. Ao invés de tratar o aborto como se fosse um problema à parte, sem relação com as condições mais gerais do engendramento, ou como se abortar fosse simplesmente o contrário de engendrar (o que, visto sob certo ângulo, também é inegável), procuraremos mostrar como a questão do aborto se encontra de certo modo incorporada na do engendramento, mas de forma diferente, conforme seja considerado como possibilidade ou como prática.

Nosso argumento será desenvolvido em dois tempos. Primeiro, procuraremos mostrar que a consideração da possibilidade de se desfazer dos seres que resultam da relação sexual é uma condição da criação dos novos seres humanos que, vindos se inscrever na carne, devem ser retomados de um modo simbólico, ou seja, pela palavra e, de certa forma, adotados para 
se tornarem singulares. Resulta então que, no caso dos seres humanos, o engendramento, em sua dimensão afirmativa, ou seja, criadora de valor, incorpora a possibilidade de sua negação, isto é, particularmente a possibilidade do aborto. Em um segundo momento, desenvolveremos a ideia de que, por razões que decorrem da imposição anterior (e não por razões exógenas), a destruição de fetos gerados, ou seja, o aborto, agora não mais como possibilidade, mas como realização, constitui um ato problemático, tendencialmente transgressivo e difícil, senão impossível, de legitimar.

Se nosso argumento se sustenta, resulta que a gramática do engendramento, compreendida em sua expressão mínima, repousa em duas imposições que se contradizem e que entram por isso potencialmente em tensão uma com a outra. O caráter muito problemático do aborto, como realização, tangeria, entre outras coisas, a seu poder de desvelamento dessa contradição, que deve permanecer, tanto quanto possível, à sombra. Ora, para que assim seja, é preciso que a presença do aborto, como realização, seja atenuada. Concretamente, isso significa que se deve ou evitar o aborto, ou realizá-lo da maneira mais discreta possível, escondido, ou então, se por uma razão ou outra ele for desvelado, que se possa considerá-lo como contingente, como circunstancial e não como a manifestação de uma regularidade.

Examinaremos em seguida as especificações que devem ser introduzidas (e os dispositivos sociais correspondentes) para que seja atenuada a tensão entre as duas imposições que levantamos de início e para que o aborto, como realização e mesmo como possibilidade, deixe o menor número de traços possível no campo semântico em que se encontra mergulhado o engendramento.

Esperamos que essa linha de argumentos permita esclarecer as propriedades intrigantes do aborto levantadas anteriormente: de um lado, sua instabilidade entre o reprovado e o tolerado e, de outro, seu relativo distanciamento do mundo da representação.

\section{Referências bibliográficas}

ALÈS, Catherine. 1998, "Pourquoi les Yanomami ont-ils des filles?". In : GODELIER, Maurice \& PANOFF, Michel (eds.). La production du corps: approches anthropologiques et historiques. Amsterdam: Overseas Publishers Association/Édition des Archives Contemporaines. 
. 2002, “A story of unspontaneous generation". In: S. Beckerman, P. Valentine, (eds.). Cultures of multiple fathers: the theory and practice of partible paternity in Lowland South America. Gainesville: University of Florida Press.

ARENDT, Hannah. 1983. La condition de l'homme moderne. Prefácio de Paul Ricœur. Paris: Calmann-Lévy.

ARISTÓTELES. 1983. Éthique à Nicomaque. Trad. e introdução de J. Tricot. Paris: Vrin.

1988. De la génération et de la corruption. Trad. e introdução de J. Tricot. Paris: Vrin.

BEAUD, Jean-Pierre. 2001. Le droit de vie et de mort, archéologie de la bioéthique.Paris: Aubier.

BOLTANSKI, Luc. 1969. Prime éducation et morale de classe. Paris: Mouton. . 1990. L'amour et la justice comme compétence. Paris: Métailié. . 1993. La souffrance à distance. Paris: Métailié.

\& THÉVENOT, Laurent. 1991. De la justification: les économies de la grandeur. Paris: Gallimard.

BOURDIEU, Pierre. 1972, Esquisse d'une théorie de la pratique, precedido de Trois études déthnologie kabyle. Genève: Droz.

. 1997. La domination masculine. Paris: Seuil.

BUECHLER, Hans C. 1971. The Bolivian aymara. New York: Holt, Rinehart \& Winston.

DESCOLA, Philippe. 1998. Les lances du crépuscule. Paris: Plon.

DEVEREUX, George. 1955. A study of abortion in primitive societies. New York: International Universities Press.

EDGERTON, Samuel. 1985. Pictures and punishment: art and criminal prosecution during the Florentine renaissance. Ithaca: Cornell UP.

FAVRET-SAADA, Jeanne. 1977. Les mots, la mort, les sorts. Paris: Gallimard. FORD, Clellan Stearns. 1964. A comparative study of human reproduction. Yale University Publications in Anthropology, no 32. Yale: Human Relations Area Files Press.

FOUCAULT, Michel. 1976. Histoire de la sexualité I: La volonté de savoir. Paris: Gallimard.

FRAENKEL, Beatrice. 1992. La signature: genèse d'un signe. Paris: Gallimard. GÉLIS, Jacques. 1984. L'arbre et le fruit. Paris: Fayard. . 1988. La sage-femme et le médecin. Paris: Fayard. 
GODELIER, Maurice. 1996, La production des grands hommes. Paris: Fayard. \& HASSOUN, Jacques (eds.). 1996. Meurtre du père, sacrifice de la sexualité: approches anthropologiques et psychanalytiques. Strasbourg: Arcanes.

\& PANOFF, Michel (eds.). 1998. La production du corps: approches anthropologiques et historiques. Amsterdam : Overseas.

HACKING, Ian. 2001. Entre science et réalité: la construction sociale de quoi? Paris: La Découverte.

HEINICH, Nathalie. 1998. Ce que l'art fait à la sociologie. Paris: Minuit. HIRSCHMAN, Albert. 1980. Les passions et les intérêts. Paris: PUF.

HORSLEY, Richard. 1979. "Who were the witches? The social roles of the accused in the European witch trials". Journal of Interdisciplinary History, v. 9 , n. 4 , p. 689-715.

JOLIVET, Muriel. 2002. "Derrière les représentations de l'infanticide ou mabiki ema", Bulletin of Faculty of Foreign Studies, n 37, p. 81-115.

JOUIN, Bernard. 1949. La mort et la tombe. Paris: I'Institut d'Ethnologie, n. 52.

KAN, Serger. 1989. Symbolic immortality: the tinglit potlach of the nineteenth century. Washington: Smithsonian Institution Press.

KANTOROWICZ, Ernst. 1989. Les deux corps du roi. Paris: Gallimard.

KARSTEN, Rafael. 1932. Indian tribes of the Argentine and Bolivian chaco: ethnological studies. Helsingsfor: Akademische Buchhandlung.

KRIPKE, Saul. 1982. La logique de noms propres. Paris: Minuit.

LA FLEUR, William. 1992, Liquid life: Abortion and buddhism in Japan. Princeton: Princeton University Press.

LE BRAS, Hervé (org.). 2000. L'invention des populations: biologie, idéologie et politique. Paris: Odile Jacob.

LÉVI-STRAUSS, Claude. 1962. La pensée sauvage. Paris: Plon.

MALINOWSKI, Bronislaw. 2001 [1993]. Trois essais sur la vie sociale des primitifs. Paris: Payot.

PHILONENKO, Alexes. 1986. La théorie kantienne de l'histoire. Paris: Vrin. PICHOT, André. 1993. Histoire de la notion de vie. Paris: Gallimard.

RICCEUR, Paul. 2000. La mémoire, l'histoire, l'oubli. Paris: Seuill.

RIDDLE, John. 1992. Contraception and abortion from the ancient world to the Renaissance. Cambridge: Harvard University Press.

ROSCH, Eleanor. 1977. "Classification of real-world objects: origins and representation in cognition”. In: JOHNSON-LAIRD, Philip N. \& WAT- 
SON, Peter C. (eds.). Thinking: readings in cognitive science. Cambridge: Cambridge University Press.

TATTERSALL, Ian. 1998, L'émergence de l'homme: essai sur l'évolution et l'unicité humaine. Paris: Gallimard.

THOMAS, Yan. 1996. "Le ventre: corps maternel, droit paternel”. Le genre humain, n. 14, p. 212-235.

VAN DER LUGT, Maaike. 1998. Le ver, le démon et la vierge: les théories médiévales de la génération extraordinaire (vers 1100 - vers 1350). Une étude sur les rapports entre théologie, philosophie naturelle et médecine. Tese de doutorado da EHESS e da universidade de Utrecht.

\section{Resumo}

Baseado na literatura que mapeia o que a pesquisa antropológica registrou sobre o aborto em diferentes sociedades, Luc Boltanski estabelece um conjunto de características invariáveis. Não há sociedade humana que não conheça a possibilidade de interrupção voluntária da gravidez. Embora seja alvo de uma condenação geral, a prática é tolerada, sendo identificada como algo em relação ao que cabe "fechar os olhos". E, em especial, o aborto sofre de um "déficit de representação". Raras vezes aparece em narrativas ou em imagens, ao contrário, por exemplo, do nascimento, da morte ou mesmo do suicídio. $\mathrm{O}$ aborto também não está associado a qualquer forma de ritual ou simbolismo. Essa característica é essencial para o autor explicar sua posição no processo de engendramento de novos seres humanos singulares, que é um processo tanto biológico quanto simbólico.

Palavras-chave: aborto; engendramento; representações.

\section{Abstract}

Based on literature mapping out what anthropological research has recorded about abortion in different societies, Luc Boltanski establishes a set of unchanging characteristics. There is no human society unaware of the possibility of voluntarily interrupting pregnancy. Although it is the target of general condemnation, the practice is tolerated, being identified as something on which to "turn a blind eye." Particularly, abortion suffers from a representational "deficit". It rarely appears in narratives or images - differently from, for instance, birth, death or even suicide. Furthermore, abortion is not associated to any form of ritual or symbolism. Such trait is essential for the author to explain his stance on the process of engendering new unique human beings, which is both a biological and $s$ symbolic process.

Key words: abortion; engendering; representations. 